\title{
Review \\ Nitrogen Gap Amelioration Is a Core for Sustainable Intensification of Agriculture-A Concept
}

\author{
Witold Grzebisz *(i) and Remigiusz Lukowiak (D) \\ Department of Agricultural Chemistry and Environmental Biogeochemistry, Poznan University of Life Sciences, \\ Wojska Polskiego 28, 60-637 Poznan, Poland; remigiusz.lukowiak@up.poznan.pl \\ * Correspondence: witold.grzebisz@up.poznan.pl; Tel.: +48-618-487-788
}

Citation: Grzebisz, W.; Łukowiak, R. Nitrogen Gap Amelioration Is a Core for Sustainable Intensification of Agriculture-A Concept. Agronomy 2021, 11, 419. https://doi.org/ 10.3390/agronomy11030419

Academic Editor: Claudio Ciavatta

Received: 21 January 2021

Accepted: 22 February 2021

Published: 25 February 2021

Publisher's Note: MDPI stays neutral with regard to jurisdictional claims in published maps and institutional affiliations.

Copyright: (c) 2021 by the authors. Licensee MDPI, Basel, Switzerland. This article is an open access article distributed under the terms and conditions of the Creative Commons Attribution (CC BY) license (https:// creativecommons.org/licenses/by/ $4.0 /)$.

\begin{abstract}
The main reason for the development of the yield gap in crop production is the inefficient management of nitrogen $(\mathrm{N})$. The nitrogen gap (NG) cannot be ameliorated without an indication and quantification of soil characteristics that limit $\mathrm{N}$ uptake by a crop plant. The insufficient supply of $\mathrm{N}$ to a plant during its cardinal stages of yield formation is a result of two major-variabilities. The first is spatial variability in the soil characteristics responsible for water supply to a plant, also serving as a nutrient carrier. The second is a vertical variability in soil factors, decisive for pools of available nutrients, and their in-season accessibility to the grown crop. The long-term strategy for NG cover should focus first on soil characteristics (humus stock, $\mathrm{pH}$, nutrient content) responsible for water storage and its availability to the currently grown plant. Diagnostics of plant nutrient availability should deliver data on their contents both in the topsoil and subsoil. The combined use of both classical diagnostic tools and spectral imagery is a way to divide a single field into units, differing in productivity. Remote-sensing techniques offer a broad number of tools to define the in-season crop canopy requirement for fertilizer $\mathrm{N}$ in homogenous field units.
\end{abstract}

Keywords: climatic potential yield; yield gap; nitrogen use efficiency; soil constraints; subsoil; spatial variability; remote sensing-techniques; field

\section{Food Gap and Sustainable Intensification of Agriculture}

The global human population, depending on the scenario, will reach 9-10 billion in 2050. Some prognoses of food requirements in 2050, based on the level of food production in 2005, fluctuate from $50 \%$ to $110 \%$ [1,2]. The analysis made by Hunter et al. [3] showed a much lower level of food demand in 2050 compared to 2010, ranging from $25 \%$ to $70 \%$. The effective management of global food demand in 2050 should be a result of the simultaneous implementation of three complementary strategies, termed "mega-wedges" [4]. They are as follows: (i) filling the food production gap, (ii) decreasing food losses in the entire food chain, (iii) reduction in the worldwide food demand. The relative contribution of each particular mega-wedge in food security control has been assessed as $46 \%, 33.6 \%$, and $20.4 \%$, respectively. The second strategy does not include only direct losses of energy and proteins in the food chain, but also reduced productivity of soil and water $(10.4 \%)$. This means that above $55 \%$ of the future food demand directly depends on efforts oriented on covering the food production gap. With respect to food losses, it is necessary to stress that the net excess of the global protein supply is almost equal to its intake by humans $(36 \%$ vs. $44 \%$ ) [5]. It can be, therefore, concluded that the management of the food production chain requires significant changes in agriculture. The conceptual (diagnostic, management, techniques, technology) preparation of the agriculture sector for a considerable increase in food production in the coming 30 years is the key challenge for the present generation.

The current level of food production is a function of two main factors, i.e., (i) actual crop yield, (ii) crop yield improvement. The actual yield of a particular crop in a strictly defined locality (field) is a result of the efficiency of production inputs under the course of 
meteorological conditions during the growing season $[6,7]$. The realization of the second target depends on progress in (i) breeding of new cultivars, (ii) improvement in water efficiency (WUE), (iii) improvement in nitrogen use efficiency (NUE). It is necessary to remember that the success of the Green Revolution, resulting in the significant increase of yields of major crops (cereals, rice, maize) was a result of the induced synergism between new, high-yielding cultivars, high rates of applied fertilizer nitrogen $\left(\mathrm{N}_{\mathrm{f}}\right)$, and a high level of crop protection, based on agrochemicals [8]. An insufficient level of the required synergism between these three main factors has resulted in stagnation in the world average yields of main crops during the last two decades [9]. The necessary annual rate of yield increase of four global crops. i.e., maize, rice, wheat, and soybean to cover the food gap in 2050 would have to reach $2.4 \%$. The current yearly rate of yield increase for these four crops is far below the assumed threshold, being at the level of $1.6 \%, 1.0 \%, 0.9 \%$, and $1.3 \%$, respectively [10]. For example, the genetic progress in nitrogen use efficiency for wheat in the years $1985-2010$ was only in the range of $0.30-0.37 \% \mathrm{y}^{-1}$. This was a result of the increased value of the Nitrogen Harvest Index (NHI), i.e., the relative amount of $\mathrm{N}$ accumulated in grain [11].

Future progress in food production, in fact, will depend on two key drivers. The first is high-tech intensification, based on highly productive cultivars of main crop plants, and the efficient use of mineral fertilizers and other agro-chemicals. This strategy has been responsible for about $\frac{3}{4}$ of the global food production increase in the last 85 years. The remaining $\frac{1}{4}$ was due to the increase in the area of arable land, mainly in less-developed countries. The productivity of the newly cultivated soils is to a great extent driven by their natural fertility. In the future, this option will be strongly limited due to the lack of high or even medium fertile soils. The primary resources of potential arable land are extensive pastures and tropical forests. The key disadvantage of the first is a shortage of water and of the second, low fertility, mainly due to high acidity and a shortage of essential nutrients. In addition, this option requires a considerable financial input to increase soil fertility, as a prerequisite of an economically and environmentally sound level of production [12,13].

The progressively increasing demand for food, resulting from the permanently growing human population, is in contradiction to the concept of sustainable development of agricultural production. The most advanced scenarios of a sustainable approach to food production assume a massive reduction or even the elimination of $\mathrm{N}$ fertilizers and pesticides. The main objective of this restrictive view of agriculture is to arrest the degradation of both local and global environments [14]. In the current and future reality, food demand is too high to completely abandon modern production measures $[15,16]$. A realistic view of sustainable agricultural development, termed as sustainable intensification of agriculture (SIA), defines this concept as a process or production system where yields are increased without an adverse impact on the environment and without the cultivation of low-quality land [17]. A less sophisticated, but at the same time a more practical definition of SIA, has been proposed by Smith [18]. The core of this definition is to produce more, and high-quality food per unit of used and applied production measures, taking into account both soil fertility and externally applied measures (fertilizers, pesticides, fuel) on the one hand, and protection of the existing ecosystems against damage on the other hand. These opinions are summarized in the concept of twin objectives, which relies on the assumption that agricultural development, including new tools, both implemented as new production technologies, production systems, and management, has to ensure the stability of the global ecosystem $[19,20]$.

The area of arable land and the amount of available water during the growing season of a particular crop plant are key factors that limit food production for a country, region, or field. A rise in food production cannot be based solely on the increased efficiency of water usage. As reported recently by Grafton et al. [21], based on an analysis of numerous methods of crop plant irrigation, no direct substitution between water and nitrogen was observed. The key factor limiting yield, as results from this study, is nitrogen. The authors clearly stated that the greatest challenge to the progress of crop plant productivity depends 
on the improvement in $\mathrm{N}$ management. The required rate of food production increase to cover the food gap by 2050 can be achieved by an adequate supply of fertilizers, both nitrogenous, and those balancing $\mathrm{N}$, i.e., containing $\mathrm{P}, \mathrm{K}, \mathrm{Mg}$, $\mathrm{S}$, and micronutrients. Scenarios of nitrogen fertilizers $\left(\mathrm{N}_{\mathrm{f}}\right)$ consumption in agriculture to cover the food production gap vary 3-fold, i.e., from $85 \mathrm{Mt} \mathrm{N} \mathrm{y}^{-1}$ to $260 \mathrm{Mt} \mathrm{N} \mathrm{y}^{-1}$ [22]. In the model of $\mathrm{N}$ flows by Conijn et al. [23], the total consumption of $\mathrm{N}_{\mathrm{f}}$ will increase to $181 \mathrm{Mt}^{-1}$, i.e., by $76 \%$ in 2050 as compared to 2010 (103 $\mathrm{Mt} \mathrm{N} \mathrm{y}^{-1}$ ). The increased $\mathrm{N}_{\mathrm{f}}$ consumption will lead, however, to a simultaneous increase in losses of its active compounds into the environment. The $\mathrm{N}$ loss in 2050 is projected to lie in the range of $102-156 \%$ with respect to 2010 [24].

Any increase in the production efficiency of both key agronomic factors, i.e., water and nitrogen, depends on the soil status of all the other production factors decisive for their efficiency. The production of phosphorus fertilizers to cover crop plant requirements for this nutrient is set to increase in the period 2010-2050 by $32 \%$ (from 17.9 to $23.7 \mathrm{Mt} \mathrm{P} \mathrm{y}^{-1}$ ) [23]. An analysis made by Pradhan et al. [25] showed that to fulfill food production goals in 2050 the consumption of N, P, and $\mathrm{K}$ fertilizers will increase in the range of $45-73 \%$ for $\mathrm{N}$, $22-46 \%$ for $\mathrm{P}_{2} \mathrm{O}_{5}$, and 2-3-fold for $\mathrm{K}_{2} \mathrm{O}$, respectively, compared to 2010 . The sustainable intensification of agriculture cannot be realized without taking into account other nutritional factors that limit the productivity of water and nitrogen, such as magnesium, sulfur, and micronutrients [26,27].

The principal challenge to the concept of sustainable intensification in agriculture is to develop effective diagnostic and management tools oriented to the increased efficiency of the applied fertilizer nitrogen. Its realization is a prerequisite for decreasing the pressure of losses of its active forms to the local and, as a consequence to the global environment. These twin objectives can be successfully realized, provided there is a recognition and a simultaneous amelioration of factors constraining the productivity of nitrogen both in the critical stages of yield formation by the currently grown crop, and resulting from the spatial variability of its supply to plants.

\section{Yield Potential and Yield Gap}

\subsection{Water Limited Yield-WLY}

The yielding potential of a particular crop plant expresses its genetic potential for the exploitation of solar radiation and $\mathrm{CO}_{2}$ fixation [28]. Yield potential $\left(\mathrm{Y}_{\mathrm{p}}\right)$, as proposed by Evans and Fisher [29], defines the maximum attainable yield of a crop cultivar grown under conditions of the non-limiting supply of nutrients, and effective control of pests and diseases. These growth conditions can be achieved provided the implementation of irrigation to the currently grown crop [30]. Water and nitrogen are classified as factors limiting yield [28].

The importance of water supply to crop plants during the growing season is wellknown to farmers. A temporary shortage of water is a natural feature of natural, i.e., non-irrigated agriculture [31]. Therefore, in practice a much more adequate term is water limited-yield (WLY, $\mathrm{Y}_{\mathrm{w}}$ ), i.e., $\mathrm{Y}_{\mathrm{p}}$ defined under natural water supply to crop plants. The really attained yield, in fact, depends on the unit productivity of water (water-useefficiency-WUE). This index expresses the amount of yield per total volume of evaporated and transpired water during a life-cycle of a currently grown crop [32]:

$$
\mathrm{WUE}=\mathrm{Y}_{\mathrm{a}} / \mathrm{ET}_{\mathrm{a}}
$$

where:

WUE-water-use-efficiency, $\mathrm{kg}$ yield $\mathrm{mm}^{-1}$ or $\mathrm{m}^{-3}$ of water;

$\mathrm{Y}_{\mathrm{a}}$-actual yield, $\mathrm{kg}$, $\mathrm{t} \mathrm{ha}^{-1}$;

$\mathrm{ET}_{\mathrm{a}}$ - water use (transpired and evaporated water), $\mathrm{mm}, \mathrm{m}^{3}$.

Two methods can be used as simple and practical tools to calculate $Y_{w}$. The first is the FAS procedure (French and Schulz approach-FAS). This method is based on the assumption that the yield increase under the same environmental conditions is directly related to the increase in WUE [33]. The FAS method of water productivity calculation 
is composed of three components: (i) the maximum water productivity (TE), (ii) the quantities of water from current precipitation, (iii) the size of water resources in the soil volume rooted by the currently grown crop. The water-limited yield, (WLY) is calculated based on the equation:

$$
W L Y=T E\left(R-\Sigma E_{S}\right)+W R
$$

where: TE refers to the transpiration efficiency TE (TE $=k / \mathrm{VPD} ; k$-biomass /transformation ratio; VPD—vapor pressure deficit; $\mathrm{R}$ - the sum of rainfall during the growth period; $E_{\mathrm{s}}$ - the seasonal soil evaporation, equal to $110 \mathrm{~mm}$, WR -water reserves in the rooted soil volume.

The yield gap can be defined as the difference between the yield resulting from the effect of water available to plants during the growing season, i.e., the water-limited yield (WLY) and the actual yield $\left(\mathrm{Y}_{\mathrm{a}}\right)$ :

$$
\begin{gathered}
Y G=W L Y-Y_{a} \\
Y G_{f}=1-\left(Y_{a} / C P Y\right)
\end{gathered}
$$

The key component in Equation (2) is the TE index. Originally, it was set for wheat

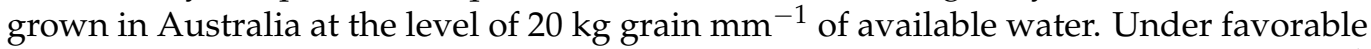
growth conditions, as stated by Passioura [34], this index can reach up to $30 \mathrm{~kg}$ grain $\mathrm{mm}^{-1}$. As reported by Grzebisz et al. [26], TE is sensitive to the amount of supplied water and nutrients, ranging during the critical stages of spring triticale growth, from 14 to $39 \mathrm{~kg}$ grain $\mathrm{mm}^{-1}$. The practical advantage of the $\mathrm{Y}_{\mathrm{w}}$ calculation, based on the FAS approach, is to quantify the yield loss due to inefficient water management. The fraction of the yield gap $\left(Y G_{f}\right)$ is a relative measure (a value, extending from 0 to 1) of the yield gap (YG) due to unfavorable growth conditions with respect to those created by the potential water supply (WLY) to the currently grown plant. As shown in Figure 1, the highest WLY was recorded in the wet year (1997). Irrigation applied to winter wheat during the critical stages of yield component formation, i.e., stem elongation and heading did not result in a yield increase. The highest values of the $\mathrm{YG}_{\mathrm{f}}$, measured on the irrigated plots, indicate that water was not exploited by wheat due to the presence of other growth constraints. In contrast, the artificial reduction in the water supply (the treatment with imposed drought-D) to wheat during the critical period of yield component formation, resulted in a slightly lower grain yield. However, a much higher level of water exploitation was recorded, as indicated by much lower $Y G_{f}$ indices, especially on the $\mathrm{K}$ fertilized plot ( 0.11 vs. 0.29 on the irrigated plot, I). The other two years were characterized by a natural water shortage during the stem elongation period (1998), or during the grain filling period (1999). As a result, the $\mathrm{YG}_{\mathrm{f}}$, in general, approached zero, indicating that actual yields were close to the potential productivity of water. The negative values of $\mathrm{YG}_{\mathrm{f}}$ stress the effect of other growth factors, which increased water productivity. This phenomenon was observed on treatments with the imposed drought, revealed most frequently on the K-treated plots. The presented data corroborates the main assumption of the FAS procedure of WLY calculation that WUE depends on the amount of water available to the currently grown crop. The $Y_{\mathrm{f}}$ index clearly reflects both the status of water management and soil fertility status.

\subsection{Climatic Potential Yield-CPY}

The maximum attainable yield of a particular crop, typical for the climatic region, is determined by the prevailing meteorological conditions. Based on this assumption Licker et al. [35], proposed to use the term, the climatic potential yield (CPY), instead of the less precisely defined, Yield Potential. The CPY can be defined as the maximum yield of a crop plant cultivar grown under a natural water supply, provided the optimization of other growth conditions. The yield gap (YG) is calculated based on the algorithm:

$$
Y G=C P Y-Y_{a}
$$




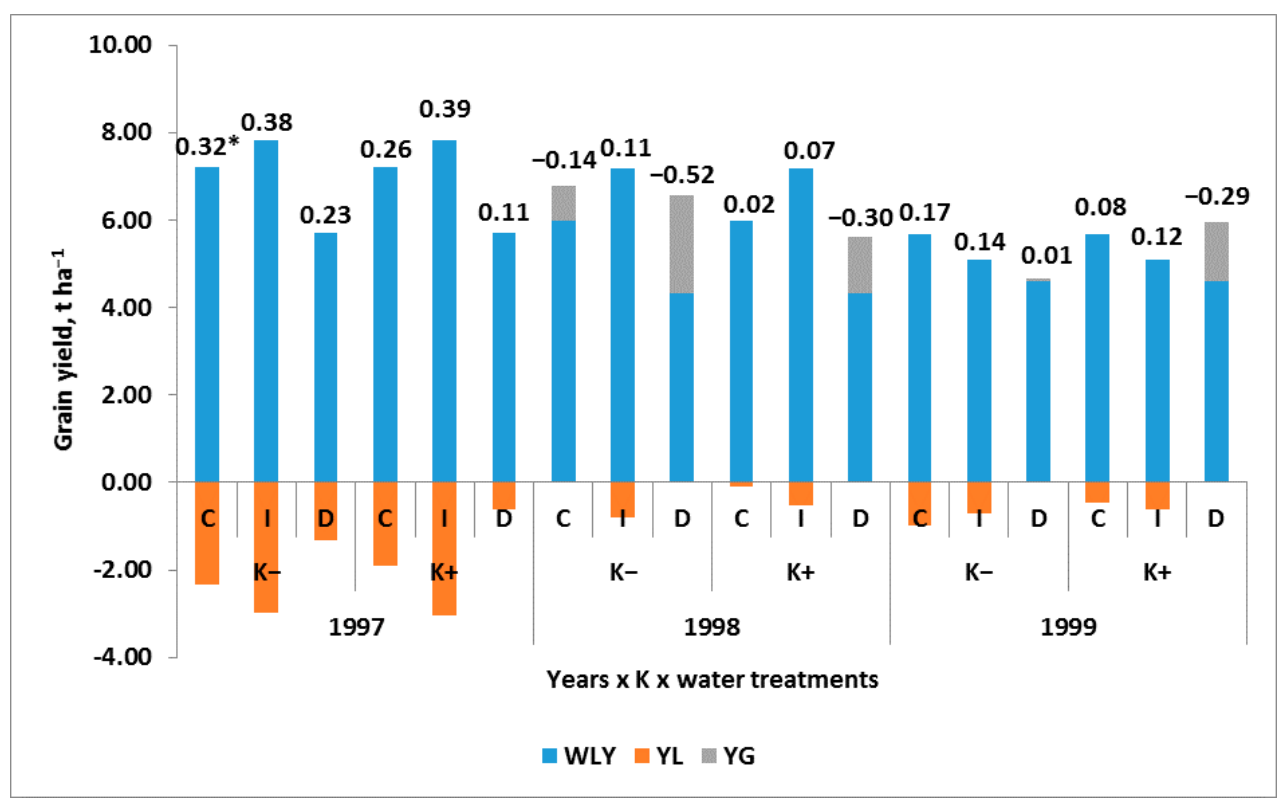

Figure 1. Graphical presentation of Water Limited Yield and loss/gain yield of winter wheat. Legend: WLY—water-limited yield; YL—yield loss; YG—yield gain; 0.32—-the yield gap fraction; C—water control; I, D-plots irrigated or with imposed drought by water shortage during stem elongation and heading. (Author's own result; unpublished) ${ }^{*}$ yield gain $(-) /$ yield loss.

The fraction of the yield gap $\left(\mathrm{YG}_{\mathrm{f}}\right)$ is a relative measure (a value, extending from 0 to 1 ) of the $Y_{a}$ distance to the yield defined by the dominant weather conditions within a given climatic region (see Equation (4)). $\mathrm{YG}_{\mathrm{f}}$ values approaching zero, indicate that meteorological conditions during the growing season were favorable, allowing the attainment of the climatic yielding potential by the grown crop. The best source of CPY data are experiments conducted by accredited Experimental Stations. An example of CPYs and their respective indices are shown in Table 1. The differences between CPY and $Y_{a}$ for winter wheat were extremely pronounced. The calculated $\mathrm{YG}_{\mathrm{f}}$ accounted on average for $58 \%$ for winter wheat as compared to $26 \%$ for sugar beets. The low year-to-year variability of this index for both crops indicates (i) stability of the CPY for these two crops, irrespective of weather variability during the growing season, (ii) the presence of other growth factors affecting the actual yield. The main reasons for the recorded difference between winter wheat and sugar beets are soil conditions. In Poland, winter wheat, despite high requirements for soil fertility, is cultivated on a broad range of soil agronomic classes [36]. In contrast, sugar beets are cultivated on very fertile soils [37]. The second growth factor, significantly impacting the CPY of wheat, is the level of crop protection and the level of applied N. The higher input of agronomic measures resulted in a CPY increase of $13 \%$.

Table 1. The Climatic Yield Gap for basic seed crops in Poland, $\mathrm{t} \mathrm{ha}^{-1}$.

\begin{tabular}{|c|c|c|c|c|c|c|c|c|c|c|c|}
\hline \multirow{2}{*}{ Years } & \multicolumn{7}{|c|}{ Winter Wheat } & \multicolumn{4}{|c|}{ Sugar Beet } \\
\hline & $\mathrm{CPY}_{\mathrm{a} 1}$ & $\mathrm{CPY}_{\mathrm{a} 1}$ & $Y_{a}$ & $\mathrm{YG}_{\mathrm{a} 1}$ & $\mathrm{YG}_{\mathrm{a} 2}$ & $Y_{G_{f a 1}}$ & $\mathrm{YG}_{\mathrm{fa} 1}$ & CPY & $Y_{a}$ & YG & $Y_{G_{f}}$ \\
\hline 2016 & 7.67 & 8.77 & 4.72 & 2.95 & 4.05 & 0.38 & 0.46 & 88.4 & 66.5 & 21.9 & 0.25 \\
\hline 2017 & 8.21 & 9.76 & 5.11 & 3.10 & 4.65 & 0.38 & 0.48 & 88.9 & 67.9 & 21.0 & 0.24 \\
\hline 2018 & 7.65 & 8.66 & 4.30 & 3.35 & 4.36 & 0.44 & 0.50 & 80.5 & 59.9 & 20.6 & 0.26 \\
\hline 2019 & 8.36 & 9.17 & 4.64 & 3.72 & 4.53 & 0.44 & 0.49 & 80.0 & 57.5 & 22.5 & 0.28 \\
\hline 2020 & 9.31 & 10.19 & 5.06 & 4,25 & 5.13 & 0.42 & 0.50 & - & - & - & - \\
\hline Mean & 8.24 & 9.31 & 4.77 & 3.47 & 4.54 & 0.42 & 0.49 & 84.5 & 63.0 & 21.5 & 0.26 \\
\hline $\mathrm{SD}$ & 0.68 & 0.65 & 0.33 & 0.52 & 0.40 & 0.04 & 0.02 & 4.86 & 5.00 & 0.9 & 0.02 \\
\hline $\mathrm{CV}, \%$ & 8.2 & 7.0 & 7.0 & 15.0 & 8.9 & 8.7 & 3.7 & 5.8 & 8.0 & 4.0 & 7.5 \\
\hline
\end{tabular}

CPY - the climatic yield potential; $Y_{a}$-actual yield; $Y G$-yield gap; $\mathrm{YG}_{\mathrm{f}}$-the yield gap fraction; a1, a2-medium and high input of production measures (crop protection + higher $\mathrm{N}$ rate); $\mathrm{SD}$-standard deviation; $\mathrm{CV}$-coefficient of variation. 


\subsection{Partial Factor of Productivity of Nitrogen-PFP $P_{N}$}

Nitrogen is, assuming the same meteorological conditions (precipitation) for a given locality (region), the key growth factor limiting yield [28,38]. Hence, the amount of $\mathrm{N}_{\mathrm{f}}$ or the whole $\mathrm{N}$ input at the beginning of the growing season becomes the principal independent variable, affecting both the plant growth rate during the growing season and its yield $[39,40]$. The efficiency of $\mathrm{N}_{\mathrm{f}}$ can be determined, using the concept of the partial factor productivity of fertilizer nitrogen, $\left(\mathrm{PFP}_{\mathrm{N}}\right)$ [41]. This approach is frequently applied for making a country-to-country comparison [42]. The procedure to calculate the maximum attainable yield $\left(\mathrm{Y}_{\mathrm{attmax}}\right)$, and in consequence, the nitrogen gap (NG) based on $\mathrm{PFP}_{\mathrm{N}}$, requires data on the unit productivity of the applied $\mathrm{N}_{\mathrm{f}}$ under optimum growth conditions, i.e., the ample availability of nitrogen. The following set of equations can be used to calculate both indices:

$$
\begin{array}{cc}
\text { Partial factor productivity of } \mathrm{N}_{\text {in }} & \mathrm{PFP}_{\mathrm{Nf}}=\mathrm{Y} / \mathrm{N}_{\mathrm{f}}\left(\mathrm{kg} \text { seeds kg }{ }^{-1} \mathrm{~N}_{\mathrm{f}}\right) \\
\text { Maximum attainable yield } & \mathrm{Y}_{\mathrm{attmax}}=c \mathrm{PFP}_{\mathrm{Nf}} \cdot \mathrm{N}_{\mathrm{f}}\left(\mathrm{t}, \mathrm{kg} \mathrm{ha}^{-1}\right) \\
\text { Yield Gap } & \mathrm{YG}=\mathrm{Y}_{\mathrm{attmax}}-\mathrm{Y}_{\mathrm{a}} \\
\text { Nitrogen Gap } & \mathrm{NG}=\mathrm{YG} / c \mathrm{PFP}_{\mathrm{Nf}}
\end{array}
$$

To delineate the role of $\mathrm{PFP}_{\mathrm{Nf}}$ on yield, the critical value of $\mathrm{PFP}_{\mathrm{Nf}}$ has to be defined in the set of data obtained. The critical $\operatorname{PFP}_{\mathrm{Nf}}\left(\mathrm{PFP}_{\mathrm{Nf}}\right)$ is calculated as the average of the third quartile (Q3) of $\mathrm{PFP}_{\mathrm{Nf}}$ values measured for each crop in a particular growing season. To determine the $c \mathrm{PFP}_{\mathrm{Nf}}$, the calculated $\mathrm{PFP}_{\mathrm{Nf}}$ values are ranked in ascending order. The third quartile comprises values above the $75^{\text {th }}$ percentile. The $c \mathrm{PFP}_{\mathrm{Nf}}$ is the average of the $\mathrm{PFP}_{\mathrm{Nf}}$ values of the Q3. In the last step of the procedure, the nitrogen gap (NG) is calculated by transforming YG into the amount of the available $\mathrm{N}$, but not used by the crop during the growing season [39]. The NG data can be used to prepare a graphical model of the efficiency of available N, i.e., mineral nitrogen present in the soil/crop plant system during the growing season of an actually grown crop. As shown in Figure 2, $\mathrm{Y}_{\text {attmax }}$ for 32 tested fields in 2020, amounted to $8.663 \mathrm{t} \mathrm{ha}^{-1}$. Theoretically, at this yield level, the soil $\mathrm{N}_{\text {min }}$ content at wheat harvest is "zero". The excess of $\mathrm{N}_{\min }$, as indicated by negative values of NG, leads to a yield decline and vice versa. The key question is to indicate a reason for the appearance of the NG and its size. In most studied cases, it was the excess of applied $N_{f}$, concomitant with the low fertility of a soil agronomic class.

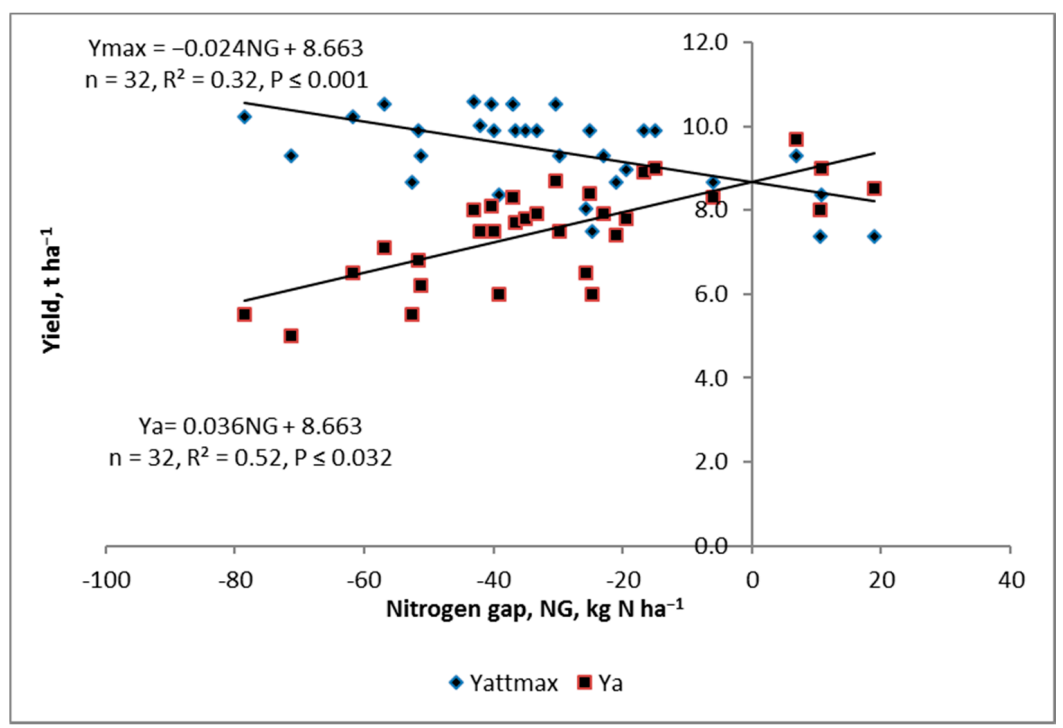

Figure 2. Trends in actual and maximum attainable yields in response to Nitrogen Gap in winter wheat. Legend: NG—nitrogen gap; $\mathrm{Y}_{\mathrm{attmax}}$ —maximum attainable yield; $\mathrm{Y}_{\mathrm{a}}$ —actual yield. 


\section{Soil Factors-Limiting Crop Plant Growth}

\subsection{Growth Factors Efficiency and Yield}

A crop yield depends on its potential to take in water and nutrients in well-defined stages of its growth [43]. Three groups of factors are responsible for the exploitation of the yielding potential of a particular crop cultivar: (i) weather conditions during the growing season, (ii) soil fertility level, (iii) soil and crop management systems [35,43]. Weather conditions during the growing season in non-irrigated agriculture are the strongest environmental factor, significantly affecting year-to-year variability in yields [44]. Soil productivity has been indicated as one of the most important objectives listed in the sustainable development goals (SDGs) by the United Nations in the 2030 Agenda for Sustainable Development [45]. Mueller et al. [46] classified natural factors constraining plant productivity into three main groups, comprising: (i) soil moisture and its thermal regime-directly related to weather variability during the growing season and to in-season changes in water availability in the soil profile, (ii) root growth pattern and nutrient uptake patterns, (iii) field topography. Soil fertility can be defined as the inherent soil potential for supply of air, water, and nutrients to the currently grown crop plant in the required amounts and chemical forms, necessary for exploiting its yielding potential [47]. The key question with respect to the optimum ranges of growth conditions for a currently cultivated plant on a given field cannot be simply answered. The main reason is the huge number of factors that affect plant growth during the growing season, and its subsequent yield. Wallace and Wallace [43] suggest the existence of more than 60 factors, grouped into seven categories, including both biophysical soil properties (five groups), weather and soil, and finally crop management methods. Based on these evaluations, the production outcome, i.e., actual yield $\left(\mathrm{Y}_{\mathrm{a}}\right)$ can be considered as a function of the climatic potential yield (CPY) and the efficiency of factors (E), affecting yield:

$$
\mathrm{Y}=\mathrm{CPY} \cdot\left(\mathrm{E}_{1} \cdot \mathrm{E}_{2} \cdot \mathrm{E}_{3} \cdot \ldots \mathrm{E}_{\mathrm{n}-1} \cdot \mathrm{E}_{\mathrm{n}}\right)
$$

The strength of each factor's impact on yield declines in accordance with its partial fraction, approaching 1.0. The value of 1.0 for a given factor indicates its optimum status with respect to the rate of plant growth, the formation of yield components, and the eventual yield.

\subsection{Soil Fertility Constraints-Humus Content and Water Resources}

During the first step in nitrogen gap (NG) amelioration, it is necessary to develop a set of effective diagnostic tools for recognizing the main soil characteristics-constraints that negatively affect plant growth. The second step should be oriented to working out a set of agronomic methods, allowing for the NG cover. Four groups of growth factors require a farmer's serious attention when evaluating the strength of soil factors that limit plant growth during the growing season. They are (i) total soil moisture amount and its availability to plants, (ii) the size of the in-season mineral nitrogen pool, (iii) pool of available nutrients responsible for $\mathrm{N}$ efficiency to plants during the growing season, (iv) plant accessibility to all sets of nutrients within the growing season.

The most important of these factors is water management before and during the growing season. World crop production systems to $60-80 \%$ depending on the amounts of water accumulated in the soil profile, strictly in the layer occupied by roots of the currently grown plant [48]. The quantity and availability of water stored in the soil profile to plants depend both on soil texture and its structure [49]). The capacity of the root zone (RZC) for water (the volumetric water capacity, VWC, at field capacity within a range of 10 and $1500 \mathrm{kPa}$ suction) is measured for crop plants down to $100 \mathrm{~cm}$ [50]. In Europe, the $\mathrm{RZC}_{100}$ for sandy soils is in the range of 50 to $100 \mathrm{~mm}$, and for loamy soils from 100 to $200 \mathrm{~mm}$.

The amount of storage and available water depends to a great extent on the content of soil organic matter (SOM, humus). In regions, or even in fields with a high contribution of sandy soil, the best option to increase VWC is to raise the humus stock (HS) in the 
soil profile. This operation can be only successful if the depth of the organic layer is increased [51]. It has been well-documented that the amount and resistance of soil humus to degradation processes is a function of soil texture [52]. Loveland and Webb [53] in an extensive review showed that the minimum content of humus required to maintain soil productivity is $1.7 \%$ for sandy soil ( $4 \%$ of clay particles) and almost $6 \%$ for clay loam ( $38 \%$ clay particles). The humus content in a particular soil is, in fact, a constant value, defined by the content of total silt and total clay. Based on this assumption Piéri [54] developed a soil degradation index, termed as the humus stability index (S), whose formula is as follows:

$$
\mathrm{S}=(\mathrm{H} / \mathrm{Si}+\mathrm{C}) \cdot 100
$$

where: S-index of soil humus stability, $\mathrm{H}$ - humus content (\%), Si and C denote silt and clay content $(\%)$, respectively.

The $S$ index is a simple index to determine the current status of soil degradation. Four classes of soil sensitivity to degradation, based on the $S$ index can be applied:

(1) $\mathrm{S}<5$ - structurally degraded soil;

(2) $5<\mathrm{S}<7-$ a great risk of soil structure degradation;

(3) $7<\mathrm{S}<9-$ a small risk of soil structure degradation;

(4) $\mathrm{S}>9$ - no risk of soil structure degradation.

The $S$ value above nine indicates that the humus content is at an optimum to protect the stability of the soil structure. In the next step in the procedure, evaluating the status of soil humus, the humus stock gap (HSG) can be calculated [55]:

$$
\begin{aligned}
& \mathrm{SHS}_{\mathrm{SD}}=\mathrm{OC} \cdot 1.7 \cdot 10 \\
& \mathrm{HSG}=\mathrm{HS}_{\mathrm{A}}-\mathrm{SHS}_{\mathrm{SD}}
\end{aligned}
$$

where:

$\mathrm{SHS}_{\mathrm{SD}}$-Standardized Humus Stock, $\mathrm{t} \mathrm{ha}^{-1} ; \mathrm{HS}_{\mathrm{A}}$-Actual Humus Stock, $\mathrm{t} \mathrm{ha}^{-1}$;

HSG-Humus Stock Gap, $\mathrm{t} \mathrm{ha}^{-1}$; OC-mean value of organic carbon content, $\mathrm{kg} \mathrm{m}^{-2}$;

1.7-constant used to recalculate the OC content into humus;

10 - constant, recalculating $\mathrm{kg} \mathrm{m}^{-2}$ into $\mathrm{tha}^{-1}$.

The yield gap/gain (YG/G), i.e., yield loss or gain, based on the humus content, can be calculated based on the formula:

$$
\text { YG/YG }=\text { HSG } \cdot 15.6
$$

where: 15.6 — constant, recalculating HSG into grain yield [56].

The OC data for the $\mathrm{SHS}_{\mathrm{SD}}$ calculation with respect to European soils were based on data reported by Batjes [57]. The average content of humus in Luvisols in the soil layer of $0.0-0.3 \mathrm{~m}$ is $85 \mathrm{t} \mathrm{ha}^{-1}$, increasing up to $154.7 \mathrm{tha}^{-1}$ in a soil profile of $1.0 \mathrm{~m}$. In Cambisols, the respective values are 117.3 and $200.6 \mathrm{t} \mathrm{ha}^{-1}$. Both figures are low as compared with Chernozems, for which the respective values are 153 and $374 \mathrm{t} \mathrm{ha}^{-1}$. The simple calculation of HSG shows that a net increase in the humus stock of $1 \mathrm{~g} \mathrm{~m}^{-2}$, which is equal to $17 \mathrm{tha}^{-1}$ of humus, results in a yield increase of $265.2 \mathrm{~kg} \mathrm{ha}^{-1}$. The potential yield increase can to a great extent be explained by the higher water-holding capacity of humus. As reported by Libohova [58] $1.0 \mathrm{~g}$ of humus holds up to 1.5 of water.

The main reason for the degradation of humus stock (HS) in arable soils is the rapid mineralization rate of the labile organic carbon pool, irrespective of soil management [59]. This process is accelerated by intensive NPK fertilization and soil plowing [60]. The regeneration of the HS in arable soil is a long-term process. The most effective amelioration strategies oriented towards an HS increase in arable soils, tested in long-term trials, rely mostly on intensive manure application. In European soils, as reported by Powlson et al. [61], expectations regarding the effect of manure are rather low. A yearly application of $10 \mathrm{t}$ manure over 90 years can raise the humus content in a soil layer of $0.3 \mathrm{~m}$ 
only by $4.8 \%$. As reported, however, by Szajdak et al. [62], a yearly application of $30 \mathrm{tha}^{-1}$ of manure to light soil over 38 years doubled the humus content. Despite the HS increase, no differences in rye yields were recorded compared to the effect of NPK application alone. The main practical disadvantage of this approach to HS increase, even in mixed farming, is its theoretical quality. This solution is not realized in farming practice due to a lack of manure. The option, applied in intensive agriculture, oriented only towards crop plant production, is the management of straw directly in the field. As frequently reported, this method of straw management can both increase the HS and yields of succeeding crops [63].

\subsection{Nutrient Availability and Crop Plant Accessibility to the Nutrient Pools}

The agronomic term nutrient availability refers to the amount of a particular nutrient taken up by the currently grown crop within a single growing season. Chemical tests of extractable nutrients are only an approximation of the amount of a given nutrient which potentially can be taken up by the crop plant [64]. In addition, the content of available nutrients is, as a rule, determined in the upper soil, limited usually to a layer of $0.2 \mathrm{~m}$ [65]. The term accessibility refers to the crop plant's access to soil pools of attainable nutrients within the growing season [64]. Plant access to a respective nutrient pool depends on the rate of root system growth, which is driven by the hormonal status of a plant, which to a great extent depends on plant access to nitrate nitrogen. A decreased supply of $\mathrm{N}-\mathrm{NO}_{3}$ to the aboveground plant parts affects the pattern of dry matter partitioning, leading subsequently to an increase of its investment into roots $[66,67]$. This crop plant strategy is oriented towards the capture of water, nitrogen, and nutrients supporting their use efficiency. It prevails in regions and soils sensitive to temporary water shortages [68,69].

The observed trends of crop plant response to irrigation are fully corroborated by the fact that ample water supply is a decisive yield factor, providing an optimum supply of nutrients, mainly N [46]. As shown in Figure 3, the yield of spring triticale decreased in accordance with the decreased amount of available water. However, the absolute and relative yield decrease, i.e., $Y G$ and $Y G_{f}$ were much lower under $\mathrm{K}$ fertilized treatment. The main reason for the observed trend variability was the impact of K application on WUE. As a rule, the WUE-Eta trend reflected the trend of $Y_{a}$, very well, but its steepness was lower on the K fertilized plots. The WUE-WLY indices showed different trends of dependence on $\mathrm{K}$ treatment. The index value, under conditions of $\mathrm{K}$ fertilizer application, increased in the opposite direction to the quantity of supplied water, i.e., from $23 \mathrm{~kg}_{\text {grain } \mathrm{mm}^{-1}}$ on the irrigated plot to almost $39 \mathrm{~kg}_{\text {grain }} \mathrm{mm}^{-1}$ on the plot with the artificial drought imposed during the stem elongation stage of triticale. It can be concluded that under natural precipitation, the yield gap can be ameliorated, at least partly, through the supply of nutrients like $\mathrm{K}$, which exert a significant impact on water and nitrogen management by crop plants $[26,70]$.

Fertilizer recommendations, except for mineral $\mathrm{N}\left(\mathrm{N}_{\min }\right)$, do not consider the content of available nutrients in the sub-soil. The total content of the majority of nutrients, taking $\mathrm{K}$ as a classic example, depends on the content of clay minerals [71,72]. The content of available nutrients is also sensitive to other soil characteristics, for example, soil $\mathrm{pH}$ (phosphorus, micronutrients); manure application, and the content of organic matter (nitrogen, phosphorus, micronutrients); fertilization, and cropping sequence (nitrogen, phosphorus) [65,71-75]. The sub-soil has numerous functions; as a source of water, nitrogen, available pools of other nutrients, and as a natural milieu for the plant root system [76,77]. As shown in Figure 4, crop plants can penetrate the soil for $\mathrm{K}$ down to a depth of $0.90 \mathrm{~m}$ of the soil profile. In the presented case, the strongest soil depletion with the $\mathrm{CaCl}_{2}$-extractable $\mathrm{K}$ was recorded for winter oilseed rape. This phenomenon is corroborated by the fact that this crop has an extremely high requirement for K during the spring vegetation [78]. The same phenomenon was observed for phosphorus. As reported by Łukowiak et al. [79], crop plants can exploit the $\mathrm{CaCl}_{2}$-extractable $\mathrm{P}$ down to $0.9 \mathrm{~m}$ of the soil profile. The authors of this study documented that the recovery of $60 \%$ of the available $\mathrm{P}$ pool was concomitant with the highest yield of winter oilseed rape (WOSR). This figure may seem 
shocking, but it refers to the $\mathrm{P}$ content in the soil solution. An open question remains as to the contribution of the sub-soil $\mathrm{P}$ pool in the total $\mathrm{P}$ taken up by the currently grown plant. In the case of seed crops, for example, WOSR, an important part of $\mathrm{P}$ is taken up by plants following the onset of flowering [80]. A permanent application of $P$ fertilizers, as documented for long-term experiments, leads to the enrichment of the sub-soil with $\mathrm{P}$. As a consequence of this operation, this pool becomes a considerable source of $\mathrm{P}$ for high-yielding crops [81]. It can be, therefore, concluded that chemical tests for the soil pools of nutrients in the subsoil cannot be limited only to the $\mathrm{N}_{\min }$ content $[82,83]$. It has been recently documented that the simultaneous determination of $\mathrm{N}_{\min }$ and some other key nutrients in the $\mathrm{CaCl}_{2}$-solution is a source of knowledge of both their pools and the occurring relationships between them [82,83].

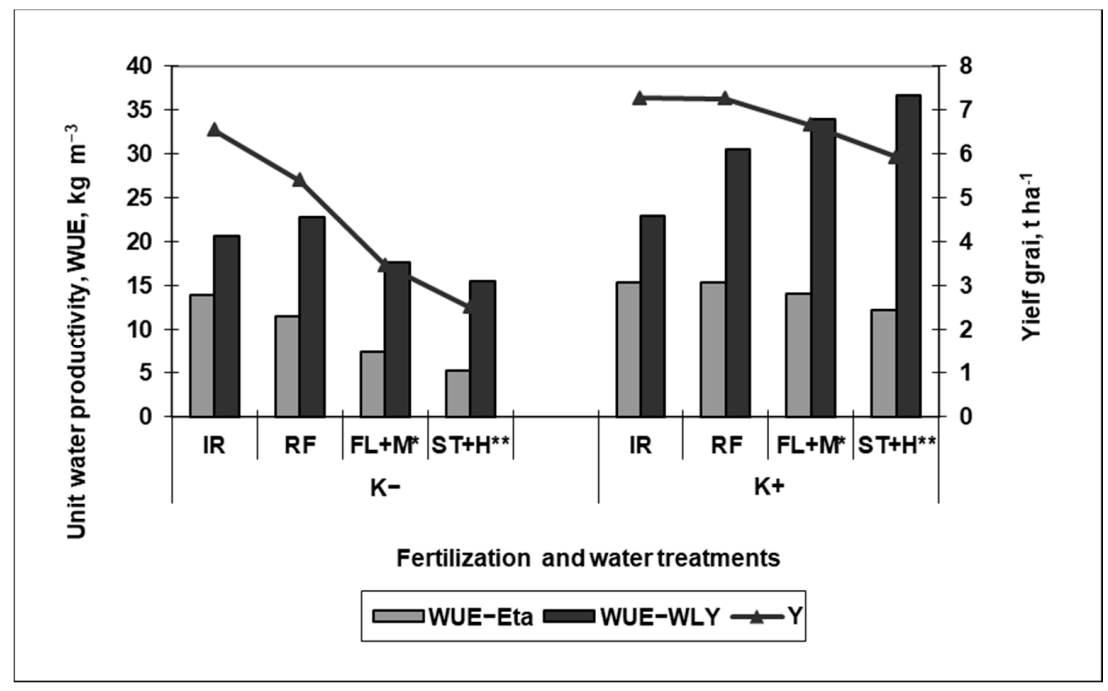

Figure 3. Effect of water treatments and potassium management on indices of water use efficiency (based on [26]. Legend: IR, RF-irrigated and rainfed water treatments; $\mathrm{FK}+\mathrm{M}, \mathrm{ST}+\mathrm{H}$-water shortage imposed at * stem elongation + heading; ${ }^{* *}$ flowering + early milk. WUE-water Use Efficiency; Eta—calculated based on evapotranspiration; WLY - calculated based on FAS approach [33].

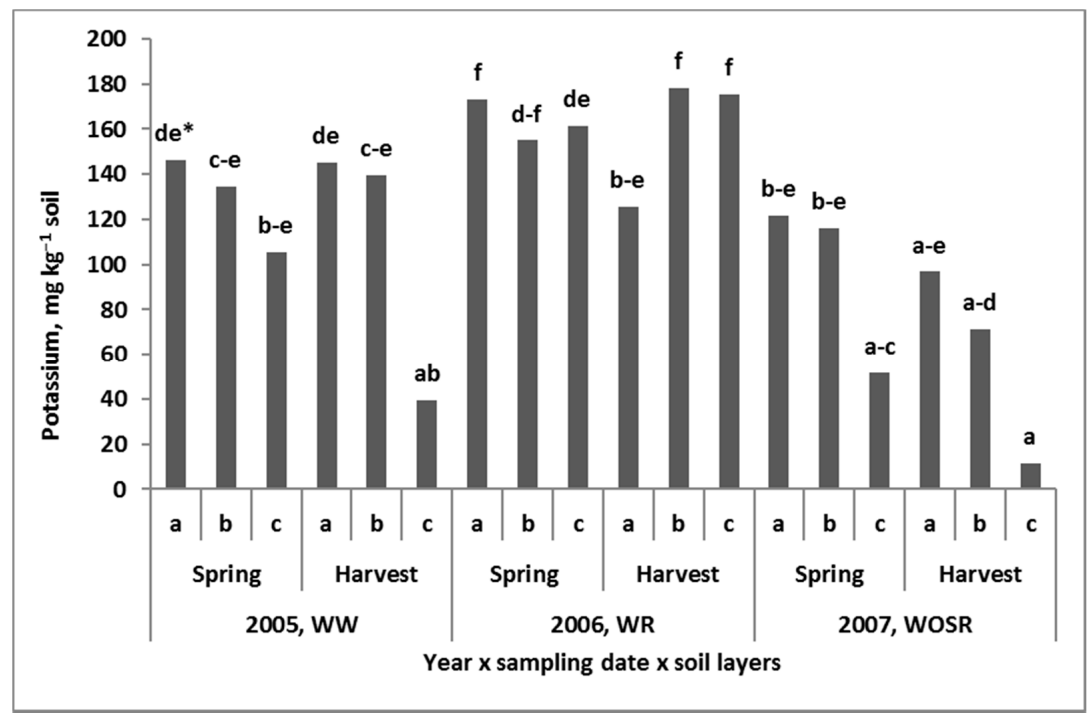

Figure 4. Status of $\mathrm{CaCl}_{2}$ extractable $\mathrm{K}$ during the growing season in three consecutive years (author's own result; unpublished). Legend: a, b, c-soil layers of 0-0.30, 0.30-0.60, 0.60-0.90 m; WW-winter wheat; WR-winter rye; WOSR — winter oilseed rape; *the same set of letters indicates a lack of significant difference between the treatments. 
The vertical trends in nutrient content variability need to be considered when working out fertilization recommendations. It has been well-documented in literature that the subsoil significantly impacts both the profile of crop rooting and in consequence the uptake of water and nutrients [76]. Rooting depth is not a constant pattern, even for the same crop. It changes due to the impact of numerous biophysical, environmental, and also soil and crop management factors [84]. The rate and habit of the root system, similarly to the shoot, undergo temporal changes during plant development and in response to its nutritional status [85]. The depletion of $\mathrm{N}-\mathrm{NO}_{3}$ at the onset of WOSR flowering in the soil layer of $0.9 \mathrm{~m}$ depth is a prerequisite of high yield [80]. The efficient uptake of $\mathrm{NO}_{3}{ }^{-}$ ions depends on the respective concentration of $\mathrm{K}^{+}$in the soil solution [86]. For the lowyielding WOSR plantation $P$ resources in the vegetative organs at the onset of flowering are sufficiently high to cover the requirements of the growing seeds. A high-yield of seeds can be achieved, but only provided there is efficient remobilization of $\mathrm{P}$ from vegetative tissues, and its simultaneous uptake from the subsoil $[77,79,87]$. It is necessary to take into account two other important facts. The first refers to the growth status of the root system. The onset of flowering results in the progressive root system dying, i.e., the rate of root mortality is higher than the appearance of new roots $[64,88]$. It is necessary to stress that the uptake of both, $\mathrm{K}$ and $\mathrm{P}$ depends to a much greater degree on the root elongation rate than on the concentration of both ions in the soil solution [89]. So far, the routine fertilizer recommendations have neglected the vertical variability of factors responsive to nutrient uptake by crop plants. This knowledge gap is one of the key reasons for the differences in the prognosis of crop production intensification in a sustainable way.

\section{The In-Season Management of Nitrogen-Cardinal Growth Stages}

The first task in the reorientation of the crop production system is to calculate the total requirement of a currently grown plant for nitrogen. This can be calculated for an average yield harvested on a particular field or based on the potential yield of a given cultivar in the same climatic region. Two additional components have to be taken into account to make a reliable estimation of the total $\mathrm{N}$ requirement by the currently grown cultivar. The first is nitrogen concentration in the main product, for example, seeds or grain. There is still ongoing scientific discussion with respect to the extent to which $\mathrm{N}$ concentration in seeds or grain is a conservative, i.e., genetically, or environmentally governed trait [90-92]. The second component refers to the partitioning of $\mathrm{N}$ taken up by the crop between the main yield, and its by-product, for example, between grain and straw. At harvest, this process refers to the value of the nitrogen harvest index (NHI), which is a conservative trait of seed crops [11,93].

Total $\mathrm{N}$ input $\left(\mathrm{N}_{\mathrm{i}}\right)$ in the soil/crop system for an assumed yield of grain/seeds is calculated based on the algorithm:

$$
\mathrm{N}_{\mathrm{i}}=\left(\mathrm{Y}_{\mathrm{CPY}} \cdot \mathrm{G}_{\mathrm{Nc}}\right) / \mathrm{NHI}
$$

where:

$\mathrm{N}_{\mathrm{i}}$-nitrogen input, $\mathrm{kg} \mathrm{ha}^{-1}$;

$\mathrm{Y}_{\mathrm{CPY}}$-climatic potential yield of the grown cultivar, $\mathrm{kg} \mathrm{ha}^{-1}$;

$\mathrm{G}_{\mathrm{Nc}}$ - grain/seed nitrogen concentration, $\mathrm{kg} \mathrm{t}^{-1}$;

$\mathrm{NHI}-$ nitrogen harvest index, a value in the range of $0.6-0.8$.

The key objective of nitrogen fertilizer $\left(\mathrm{N}_{\mathrm{f}}\right)$ application is to synchronize its application time with the crop plant requirement. The dominant factor is the stage of plant growth and the required content of $\mathrm{N}$, which progressively increases with the crop growth. The right determination of the $\mathrm{N}_{\mathrm{f}}$ dose in the critical stage of yield formation is, therefore, the decisive factor in the exploitation of the yielding potential of the currently cultivated crop. The crop demand for $\mathrm{N}$ in a particular growth stage depends on the rate of plant biomass growth, primarily driven by temperature and water supply [94]. The sum of physiologically active temperatures (GDD), and water and nitrogen supply are major factors for the quantity of biomass produced by the crop during the respective phase [95]. The rate of seed crop 
growth throughout the vegetative season is not constant. Based on this criterion, three mega-phases can be distinguished, named as canopy foundation (CF), yield component construction (YCC), and yield realization (YR) [96]. The first two periods describe the vegetative part of the plant life cycle and the third one its reproductive phases (Figure 5). The shape of the dry matter accumulation curve can be described mathematically using very sophisticated models [97]. In cereals, the CF period, extending from sowing up to the end of tillering, is responsible for the number of tillers per plant. The course of dry matter accumulation is best described by the exponential regression model. The YCC period, extending from the beginning of stem elongation up to flowering, is responsible for the set of flowers. The rate of dry matter accumulation during this period is best described by the linear regression model. The dry matter yield of wheat at the end of the CK2 can be used to make a prognosis of grain yield [98].

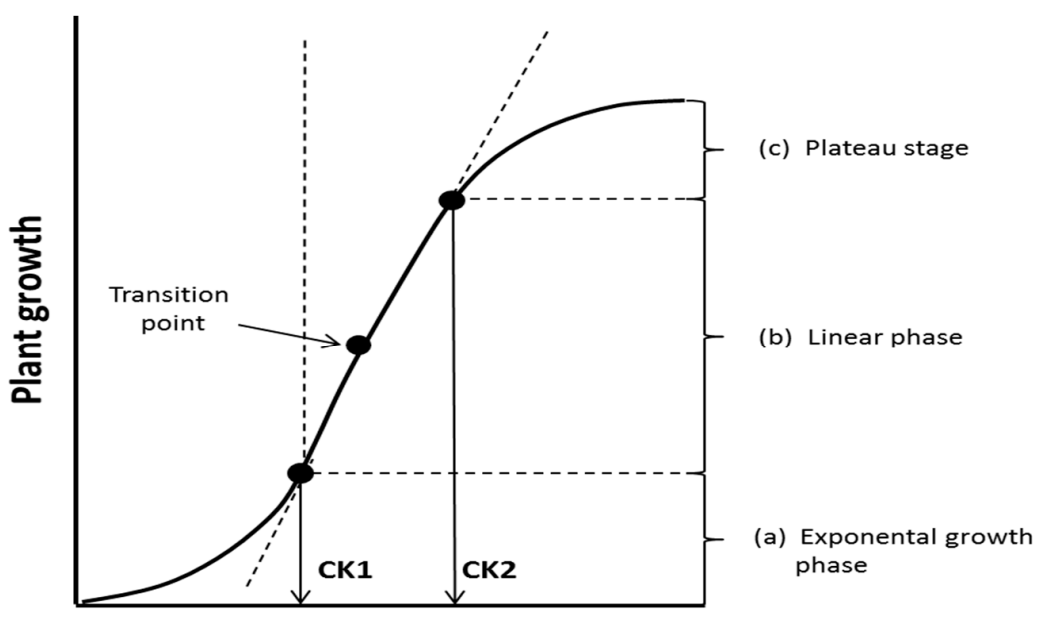

Time, growth stages

Figure 5. A conceptual pattern of dry matter accumulation by a typical seed/grain crop. Legend: CK1, CK2—cardinal stage 1 and 2, respectively (author's own concept).

The borderline stages of plant growth, which occur between the mega-phases of CF and CYC, and between the CYC and YR periods, can be named Cardinal Knots (CKs), i.e., CK1 and CK2, for the first and second borderline of consecutive mega-periods, respectively. These two CKs are decisive stages for yield component formation. For example, as shown in Figure 6, the content of soil nitrate-nitrogen (NN) during the YCC period of oilseed rape undergoes a strong depletion (=N uptake by WOSR during the YCC period). The recorded NN depletion significantly affected the seed density, which was the key yield component, determining seed yield $\left(\mathrm{R}^{2}=0.89, p \leq 0.001\right)$. What is most important, however, is the fact, that the dependence obtained clearly defines the rosette stage (BBCH 30) as the decisive stage for the yield prognosis $\left(\mathrm{NN}_{\mathrm{op}}=163.3 \mathrm{~kg} \mathrm{ha}{ }^{-1}\right.$ for $\mathrm{Y}_{\mathrm{amax}}=77.6 \cdot 1000$ seeds $\left.\mathrm{m}^{-2}\right)$. The result obtained indicates that in farming practice, the time of $\mathrm{N}_{\mathrm{f}}$ application has to precede the $\mathrm{BBCH}$ 30. In maize, the second rate of $\mathrm{N}_{\mathrm{f}}$ is applied, based on $\mathrm{N}_{\text {min }}$ determination, at the 5th leaf stage $[99,100]$.

The yield realization (YR) period commences from the onset of flowering and persists up to the physiological maturity of the plant. It can, however, be divided into two parts. The first part extends from flowering up to the watery stage of the seed/grain plant growth, i.e., to BBCH 71 (15\% of seed/grain DW). It has well been documented that nitrogen supply to a seed crop, like cereals and oilseed rape, significantly affects the degree of yield component expression. The $\mathrm{N}$ pool accumulated by the seed plant during its vegetative growth, i.e., before flowering, considerably impacts the number of seed/grain per field unit area (physiological sink capacity) [101-103]. The second part of the YR period, which begins from the early milk-stage $(\mathrm{BBCH} 72)$ and finishes at physiological plant maturity (BBCH 89/90), is termed as the grain/seed filling period (GFP, SFP). The course of dry 
matter accumulation can be described by different mathematical models, but the linear or quadratic dominate. During this particular period, grain/seed reaches its final individual weight [104].

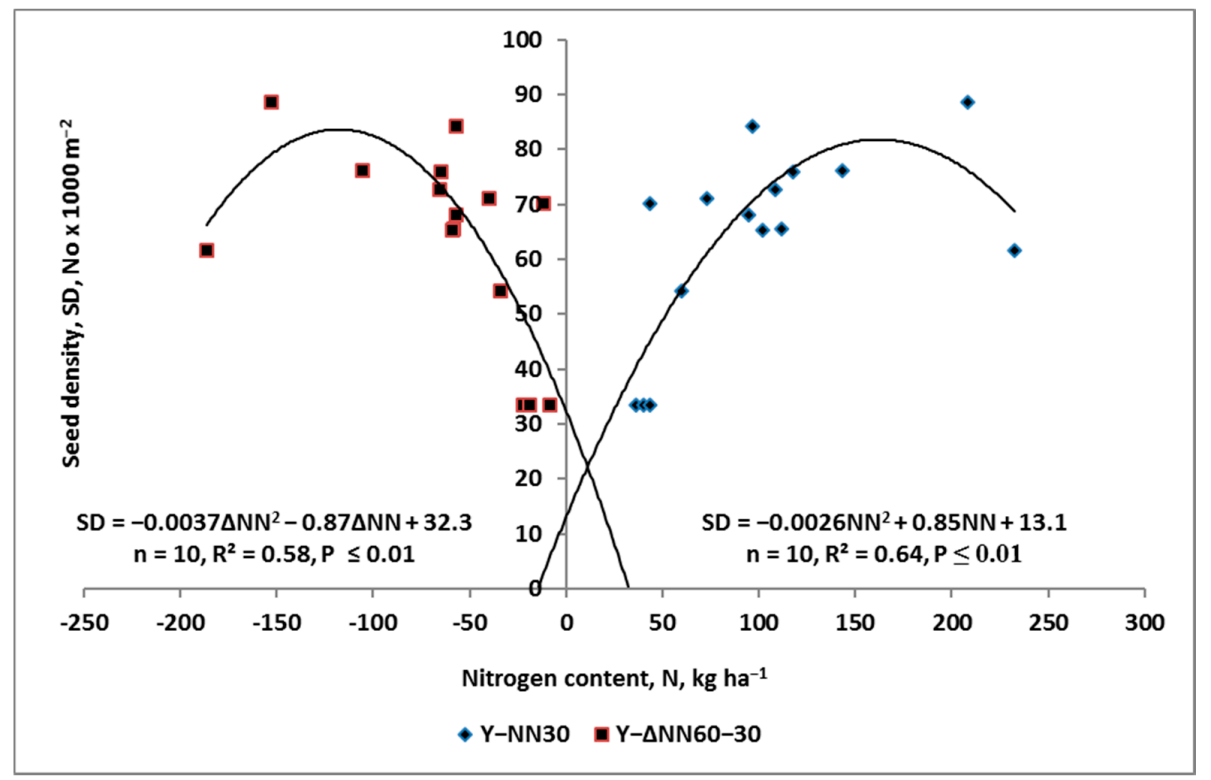

Figure 6. The response of seed density of winter oilseed rape to the content of nitrate nitrogen at the rosette stage and its uptake by the crop up to flowering. (based on [80]. Legend: NN- the content of nitrate nitrogen at $\mathrm{BBCH} 30 ; \triangle \mathrm{NN}$ - the change of the $\mathrm{NN}$ content during the period extending from the rosette up the flowering stage of WOSR growth.

Efficient in-season $\mathrm{N}$ management, including knowledge of $\mathrm{N}_{\min }$ resources, should be oriented towards covering the plant $\mathrm{N}$ requirements during the period extending from the onset of flowering to the physiological plant maturity. For the seed crops, $75-85 \%$ of the $\mathrm{N}$ finally accumulated in seeds/grains originates from the pre-flowering resources, i.e., present in vegetative plant parts $[90,105]$. Post-flowering $\mathrm{N}$ management by the crop canopy can be described by three algorithms:

$$
\begin{array}{lr}
\text { N remobilization quota: } & \mathrm{NRQ}=\mathrm{N}_{\mathrm{hv}} \mathrm{N}_{\mathrm{fl}}, \mathrm{kg} \mathrm{ha}^{-1} \\
\text { N remobilization efficiency: } & \mathrm{NRE}=\mathrm{NRQ} / \mathrm{N}_{\mathrm{fl}} \cdot 100, \% \\
\text { Post-flowering N uptake: } & \mathrm{PNUP}=\mathrm{N}_{\mathrm{t}}-\mathrm{N}_{\mathrm{fl}}, \mathrm{kg} \mathrm{ha}^{-1}
\end{array}
$$

where:

$\mathrm{N}_{\mathrm{hv}}-\mathrm{N}$ amount in vegetative organs of crop canopy at harvest, $\mathrm{kg} \mathrm{ha}^{-1}$;

$\mathrm{N}_{\mathrm{fl}}-\mathrm{N}$ amount in vegetative organs of crop canopy at the onset of flowering, $\mathrm{kg} \mathrm{ha}^{-1}$;

$\mathrm{N}_{\mathrm{t}}$ - total $\mathrm{N}$ amount in crop canopy at harvest, $\mathrm{kg} \mathrm{ha}^{-1}$.

The patterns of $\mathrm{N}$ accumulation by the plant between particular CKs during the growth of a crop are the basis for a build-up of an efficient strategy of the in-season $\mathrm{N}$ status correction. Any free choice of $\mathrm{N}_{\mathrm{f}}$ timing and its dose, as frequently observed in classic or even modern fertilization programs, does not fit the crop requirements for $\mathrm{N}$, being the main reason for its inefficiency. A sound strategy of $\mathrm{N}$ management in seed crops, despite an almost similar accumulation pattern throughout the life cycle, is crop-specific. For example, in bread wheat, the key period of yield component formation extends from CK1 to $\mathrm{CK} 2$. During this period, the requirement for $\mathrm{N}$ results from both (i) the number of grain per unit area, and (ii) the required protein content in grain [106]. Consequently, a nitrogen fertilization strategy based on the correction of the plant $\mathrm{N}$ status in both CK1 to CK2 should also take into account protein concentration in grain. As a rule, any increase in the number 
of grains per unit field area results in a protein concentration decrease [107]. Therefore, any fertilization strategy, oriented to the increase in the crude protein concentration, requires an extra $\mathrm{N}_{\mathrm{f}}$ dose, which should be applied at the end of the CK2. In maize, its nutritional status at the 5th leaf stage, which slightly precedes CK1, is decisive for the degree of yield component expression $[108,109]$. Nitrogen fertilizer should be applied just at such a time preceding this cardinal stage of maize growth because it affects the potential number of leaves and cobs. Nitrogen status in maize at the CK2, before the beginning of flowering, is important for the yield development, but it has only a predictive value [110]. In farming practice, it makes no sense to apply $\mathrm{N}_{\mathrm{f}}$ at this particular stage because the yield was already fixed in much earlier stages of maize growth.

Nitrogen efficiency depends on the supply of other nutrients needed for its uptake and utilization [70,111-113]. It is necessary to pay attention to the fact that the accumulation of $\mathrm{K}$ by major crop plants, like wheat, oilseed rape, sugar beets, or potato, is as a rule higher as compared to $\mathrm{N}[114,115]$. The maximum $\mathrm{K}$ uptake by high-yielding WOSR reaches its maximum during the phase of the main stem elongation [77,78]. It can, therefore, be concluded that an efficient uptake of $\mathrm{K}$ from the subsoil by some crops, in comparison to $\mathrm{N}$, is a necessary condition for the effective uptake of nitrogen. As recently reported by Grzebisz et al. [80], the efficient uptake of $\mathrm{NO}_{3}{ }^{-}$ions by WOSR depends on the adequate concentration of $\mathrm{K}$ and other nutrients, such as $\mathrm{Ca}$ and $\mathrm{Mg}$ in the sub-soil. All these nutrients are responsible for the development of yield components by crop plants.

One of the most important priorities in the breeding of crop plants is to increase the uptake efficiency of nutrients, especially of $\mathrm{N}$ and $\mathrm{P}$ from soil. Efficient acquisition of water and nutrients is required for the realization of both production and environmental goals. The efforts of key breeders have recently focused on the improvement of root system traits through [116-119]:

(1) Accelerating the early rate of root growth of short-season crops, for example, vegetables;

(2) Increasing root density in the topsoil to increase uptake of freshly applied fertilizers;

(3) Deeper rooting of crops grown in areas vulnerable to nitrate-nitrogen leaching.

(4) Stronger root branching to increase exploration of soil zones rich in mineral nitrogen;

(5) Increasing the density and length of root hairs for effective acquisition of phosphorus and potassium by a currently grown crop;

(6) Improvement in mycorrhiza association for effective acquisition of phosphorus and micronutrients.

\section{Yield Gap Recognition and Diagnosis of Limiting Factors}

An efficient $\mathrm{N}$ management strategy should be based on three major variables that affect the plant growth of a particular crop. Yield variability within a field is a result of (i) the stage of a crop plant growth, (ii) spatial variability in $\mathrm{N}$ uptake by plants, (iii) vertical variability in soil $\mathrm{N}$ pools, and a plant's access both to these pools and other nutrients responsible for $\mathrm{N}$ use efficiency. It is necessary to assume that the expression of yield components is a result of the growth pattern of a crop plant encoded in its early stages $[80,120]$. The principal difficulty in determining the right $\mathrm{N}_{\mathrm{f}}$ dose is the number and strength of plant growth limiting factors with respect to their spatial variability on the field. Yield, in fact, its spatial variability within a field, is the ex-post result of (i) the degree of yield constraints recognized during the growing season, (ii) the efficiency of production measures applied to ameliorate constraints limiting plant growth and yielding. The spatial variability of yield is the main reason for the necessity for dividing the entire field area into zones that differ considerably in productivity [121]. The key challenge is to find a criterion for the particular field division into zones of the same level of productivity.

The target of modern agriculture is to work out and implement a set of highly reliable diagnostic tools which will be capable of defining the methods and approaches to the efficient use of $\mathrm{N}_{\mathrm{f}}$, that are in accordance with the concept of sustainable agriculture [21,122]. This concept, taking the field as the key production unit, is based on three main objectives:

(1) fulfilling the food production gap, in fact, ameliorating the nitrogen gap; 
(2) achievement of a satisfactory level of applied production measures;

(3) a significant decrease in the negative impact of applied Nf on the environment.

\subsection{Nitrogen Use Efficiency-Limiting Factors}

The most important task for a farmer is to establish a hierarchy of factors affecting the yield gap in a particular field and recognizing their depth. Irrespective of the climatic zone, the plant growth rate and development of yield components depend on the supply of $\mathrm{N}$ and its use efficiency [38]. Nitrogen use efficiency (NUE) defines the amount of the main product, for example, seeds, grain, roots, tubers, per unit of supplied N [123]. This $\mathrm{N}$ index is composed of two sub-units, i.e., nitrogen uptake efficiency (NUtE) and nitrogen utilization efficiency (NUtE), presented as

$$
\mathrm{NUE}=\mathrm{NUpE} \times \mathrm{NUtE}
$$

The simplified interpretation of the first part of this equation, frequently used by crop breeders, mainly focuses on the amount of soil available nitrogen, i.e., to the low- and high- $\mathrm{N}$ input growth environment [124]. In fact, the amount of available $\mathrm{N}$ is a strong factor discriminating plant crop genotypes [125]. Nitrogen uptake and its subsequent transformation into plant biomass, i.e., NUtE, depends both on the physiological potential of a plant to take up $\mathrm{N}$ from its soil resources, and on soil factors limiting the rate of its uptake and subsequent utilization by a plant [113]. The spatial variability of yield clearly indicates that the amount of $\mathrm{N}$ taken up by plants of the same cultivar, i.e., having an identical yielding potential, is also spatially variable. Plants suffering from an $\mathrm{N}$ shortage due to their lower supply during the cardinal stages of yield formation are not unable to capture the same amount of solar energy compared to those growing in conditions of ample water and $\mathrm{N}$ supply. As a result, these plants are not capable of achieving the rate of growth as determined by the supply of light energy [126]. The ex-post formulated questions are: (i) at what stage of crop plant growth does the yield formation become limited by a shortage of $\mathrm{N}$ ? (ii) what is the reason for the insufficient $\mathrm{N}$ uptake? The first question has been thoroughly discussed in Part 4 . of this review. The second question should focus the farmer's attention on factors pertaining to the plant potential at a particular stage of its growth to access water and nutrient resources.

\subsection{Diagnostic Tools for the In-Season and Spatial Yield Gap Control}

The recognition of the yield gap and its size requires an implementation of a set of analytical tools with a capacity to make a reliable diagnosis of factors that limit plant growth and yield. A significant improvement in NUE is possible provided there is a reliable quantification of soil characteristics limiting both $\mathrm{N}$ uptake and its utilization by the currently grown plant. Hence, a single field is considered a basic unit in any diagnostic procedure.

The key characteristic of the yield of a currently grown crop is its spatial variability (Figure 7). The hierarchy of factors decisive for NUE is well recognized, but not always taken into account by farmers and their advisors. The primary tasks, aimed at an improved strategy for spatial $\mathrm{N}$ management, are to polygonize the field based on:

(1) the climatic yield potential (CYP), and the water-limited yield (WLY);

(2) the total requirement of the crop for nitrogen;

(3) primary soil characteristics, assuming a homogenous regime of water and nitrogen supply to the

(4) currently grown crop during its critical stages of growth;

(5) soil $\mathrm{pH}$ and the content of active aluminum, as the key factor limiting the root system growth of crop plants;

(6) contents of available nutrients, assuming a homogenous regime of their supply to the currently grown crop. 
It is necessary to create a broad set of zonation maps with respect to soil and crop characteristics to get an operational tool to establish homogenous field production units (HFPUs) $[127,128]$. Therefore, the soil water capacity and its availability to the currently grown crop determine the first criterion of the field zonation. The primary factor affecting the diffusion of ions toward the plant root in the soil is the content of available water $[50,58]$. This factor shows a strong spatial and vertical variability within the growing season, significantly affecting crop growth at cardinal stages of yield component formation [129]. As discussed in Part 3, the amount of available water is defined by the content of colloids and soil structure. Hence, the main reason for existing variabilities in the available water content is the content of mineral colloids. The primary data can be collected using the classic diagnostic procedures of soil analysis. The working out of zonation maps requires the implementation of geostatic methods $[130,131]$. The advantage of the classic methods of basic soil characteristic determination is the necessity to analyze water and nutrient resources present both in the topsoil and in the sub-soil which is rooted by a currently grown plant $[80,120]$.

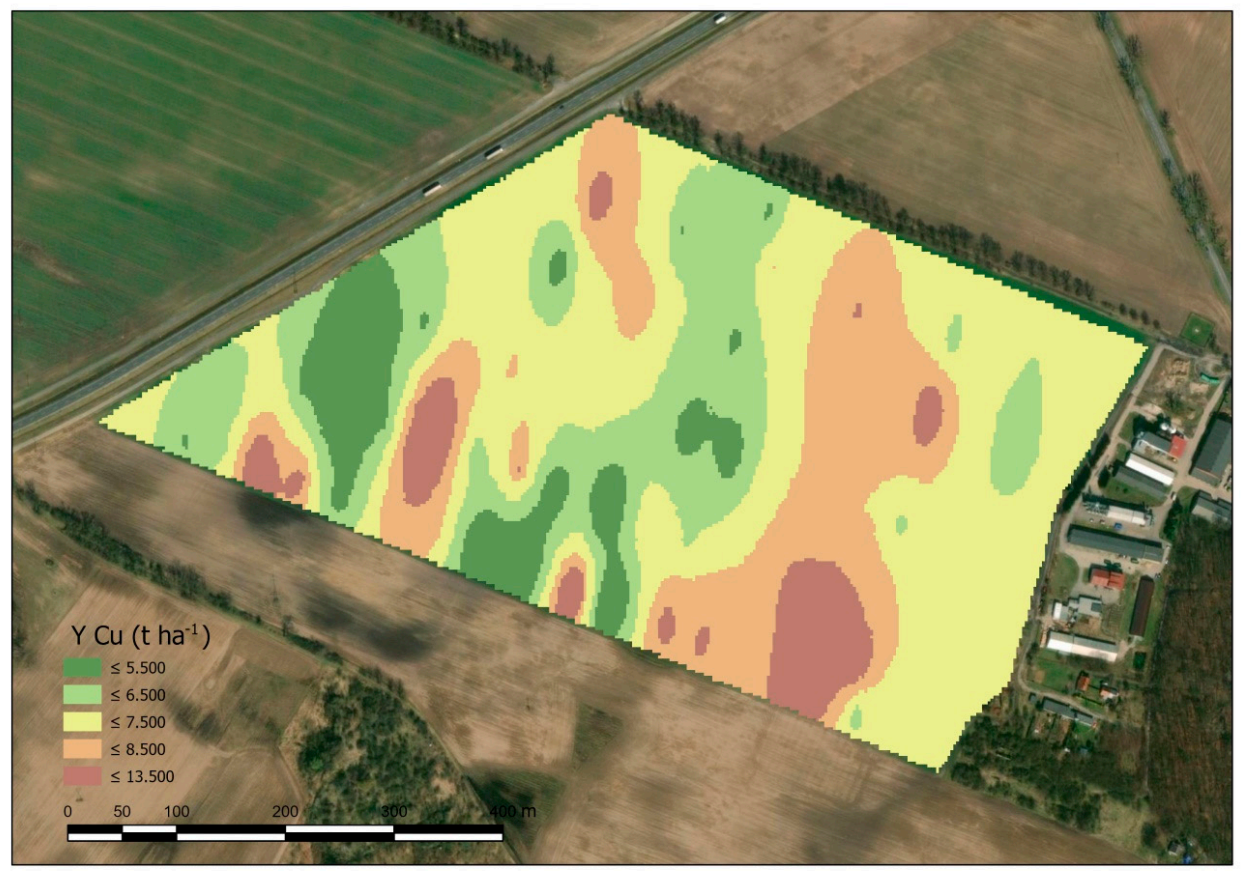

Figure 7. Spatial variability in winter oilseed rape yield expressed in cereal units (source: [128]).

The crop plant requirement for $\mathrm{N}_{\mathrm{f}}$ is the key in-season nutritional factor, responsible for the development and status of yield components. The $\mathrm{N}_{\mathrm{f}}$ dose can be calculated based on two characteristics of crop canopy:

(1) the rate biomass increase during a particular phase, in particular, within the period defined by cardinal knots (Figure 5);

(2) the trend in $\mathrm{N}$ concentration in plants during vegetative growth, with special attention to CKs.

A sequential determination of the $\mathrm{N}$ content along the growing season of a plant is a primary tool for its $\mathrm{N}$ status assessment. As a rule, during the vegetative growth of the seed crop, the proportion of active metabolic tissues (leaves) decreases stage-by-stage with respect to structural ones (stem). Consequently, the total $\mathrm{N}$ concentration in plant tissues decreases during vegetative growth, but its content in the plant progressively increases, reaching the highest value just before the onset of flowering (CK2). The temporal variability in relationships between crop dry matter biomass and $\mathrm{N}$ concentration is described by the following set of equations [132]: 
(1) Nc-the critical $\mathrm{N}$ concentration, $\%$ or $\mathrm{g} \mathrm{N} \mathrm{kg}^{-1} \mathrm{DM}$

$$
\mathrm{N}_{\mathrm{c}}=\mathrm{aW}-\mathrm{b}
$$

(2) NNI-Nitrogen nutrition index,

$$
\mathrm{NNI}=\mathrm{N}_{\mathrm{a}} / \mathrm{N}_{\mathrm{c}}
$$

where: $\mathrm{W}$-crop biomass, $\mathrm{t} \mathrm{ha}^{-1}$; $\mathrm{a}$ and $\mathrm{b}$-estimated parameters.

The $\mathrm{N}_{\mathrm{c}}$ curve is expressed as a power function, but its parameters are both crop and growth condition specific. As reported by Song et al. [133], an $\mathrm{N}_{\mathrm{c}}$ based only on rice leaf dry matter was expressed as $\mathrm{N}_{\mathrm{c}}=1.96 \mathrm{~L}_{\mathrm{DM}}{ }^{-052}$. The in-season crop $\mathrm{N}$ nutritional status can be evaluated as proposed by Chen et al. [134] for winter wheat based on three classes:

(a) $\mathrm{N}$ deficient for $\mathrm{NNI}<1.00$,

(b) $\mathrm{N}$ optimum for $1.00 \leq \mathrm{NNI} \leq 1.25$;

(c) N surplus: NNI $\geq 1.25$.

As discussed in Part 4, the yield is the outcome of the efficiency of crop production factors. A major characteristic of a crop plant is its time variability in requirements for water, nitrogen, and nutrients responsible for the efficiency of both key growth factors. In-season evaluation of plant nutritional status relies on plant destructive sampling and nutrient concentration determination in the lab. The key disadvantages of classic diagnostic methods are:

(1) ex-post data, delaying the diagnosis of plant nutritional status, and in consequence a recommendation of the $\mathrm{N}_{\mathrm{f}}$ rate;

(2) lack of data about spatial heterogeneity in plant nutritional status, resulting in

(a) uniform $\mathrm{N}$ fertilizer rate application, hardly related to the real, i.e., spatial variability in plant requirements for $\mathrm{N}$,

(b) low efficiency of applied nitrogen,

A significant increase in NUE requires the implementation of new diagnostic tools, capable of quantifying a crop plant requirement for $\mathrm{N}$ in real-time (a defined stage of plant development) and taking into account spatial differences in the productivity of field homogenous units. There has been considerable technological progress in developing different sorts of non-invasive instruments of potential use in plant nutritional status determination [135-137]. Remote sensing is a technique that offers a broad set of effective diagnostic tools to meet both production and environmental objectives. All spectral techniques rely on the plant's ability to absorb and simultaneously reflect solar radiation. Remote-sensing techniques can make a rapid assessment of plant biomass, leaf area index, nitrogen content, chlorophyll content, and finally yield [138]. The information capacity of hyper- and multi-spectral imagery is several times larger as compared to any classical diagnostic tool.

Based on the spectral imagery of a field, it is possible to create a zonal map of a temporary crop $\mathrm{N}$ status. The selection of the most reliable spectral indices depends on the sensitivity of spectral bands to both the total $\mathrm{N}$ course during plant growth (Nitrogen Dilution Curve $-\mathrm{N}_{\mathrm{c}}$ ) and canopy structure (biomass, density, $\mathrm{N}$ concentration). It has been confirmed that the intensity of solar radiation reflectance in visible light (waveband 400 to $720 \mathrm{~nm}$ ) is negatively correlated with leaf N content, while NIR reflectance is positively correlated with leaf $\mathrm{N}$ content and/or crop biomass [139]. The Normalized Difference Vegetation Index (NDVI) is the most frequently used diagnostic tool for the $\mathrm{N}$ content and crop biomass determination [140-142]. In fact, NDVI allows a reliable diagnosis of N status in cereals only during the early stages of growth. This index reaches saturation status at dense canopies $[143,144]$. This weakness has been recently overcome by developing a new set of Vegetable Spectral Indices (VIs) worked out on bands lying in other spectral regions, including the red-edge region $(700-740 \mathrm{~nm})$. Scientific reports have published data on VIs which are capable of predicting an LAI extending from 0 to 6 [145]. 


\section{Conclusions}

The sustainable intensification of agriculture is a concept which relies on the assumption of realizing two, seemingly contradictory goals, i.e., increasing food production but without a negative impact on local or global ecosystems. This twin objective can be achieved if solutions strictly oriented towards amelioration of the yield gap are put into agricultural practice, which will involve a reliance on increasing efficient nitrogen use. The inefficiency of nitrogen in the soil/crop plant system, i.e., the Nitrogen Gap, requires a three-dimensional diagnosis. The first, as a matter of fact, the major variability refers to the in-season variability in the nitrogen requirements of the currently grown crop. This gap can be filled by a synchronization of the demand of a grown plant for nutrients, in fact, driven by nitrogen applied in the required $\mathrm{N}_{\mathrm{f}}$ dose and at the right time. The recorded inefficiency of in-season applied nitrogen is due to the spatial variability of its supply. The main reason for the occurrence of the NG is both spatial and vertical variability in soil characteristics responsible for $\mathrm{N}$ uptake and its subsequent utilization by plants. The recognition of the size and strength of a plant's growth constraints, the disturbing formation of yield, is the prerequisite for dividing a field into zones of homogenous levels of productivity. Because the capacity of soil to soil water storage depends on the content of colloidal particles, the first goal of soil fertility amelioration is to increase the humus stock. This production objective is especially important for field zones naturally poor in mineral colloids. The subsequent steps in the action oriented to soil fertility amelioration depend on a farmer's ability to recognize the level of the subsoil fertility, including the content of available water and nutrients, and on the access of the currently grown crop to these resources during the growing season. A diagnosis of the soil fertility status is important for the development of application techniques of both nitrogen and nutrients, supporting its use efficiency. Classic and remote sensing techniques should be simultaneously applied to delineate the field into units of the homogenous level of productivity. Remote-sensing is the most efficient tool for the in-season diagnosis of the $\mathrm{N}$ plant status, provided it can discriminate the productivity of each field unit.

Author Contributions: Conceptualization, W.G. and R.t.; methodology, W.G.; software, R.t.; validation, R.Ł.; formal analysis, W.G.; investigation, R.Ł.; resources, W.G.; data curation, R.Ł.; writingoriginal draft preparation, R.Ł.; writing - review and editing, W.G.; visualization, R.Ł.; supervision, W.G.; project administration, R.t. All authors have read and agreed to the published version of the manuscript.

Funding: This research received no external funding.

Conflicts of Interest: The authors declare no conflict of interest.

\section{References}

1. Tilman, D.; Balzer, C.; Hill, J.; Befort, B.L. Global food demand and the sustainable intensification of agriculture. PNAS 2011, 108, 50. [CrossRef] [PubMed]

2. Le Mouël, C.; Forslund, A. How can we feed the world in 2050? A review of the responses from global scenario studies. Eur. Rev. Agric. Econ. 2017, 44, 541-591. [CrossRef]

3. Hunter, M.C.; Smith, R.G.; Schipanski, M.E.; Atwood, L.W.; Mortensen, D.A. Agriculture in 2050: Recalibrating targets for sustainable intensification. BioScience 2017, 67, 386-391. [CrossRef]

4. Keating, B.A.; Herrero, M.; Carberry, P.S.; Gardner, J.; Cole, N.B. Food wedges: Framing the global food demand and supply challenge towards 2050. Glob. Food Sec. 2014, 3, 125-132. [CrossRef]

5. Berners-Lee, M.; Kennelly, C.; Watson, R.; Hewitt, C.N. Current global food production is sufficient to meet human nutritional needs in 2050 provided there is radical societal adaptation. Elem. Sci. Anth. 2018, 5, 52. [CrossRef]

6. Brevik, E.C. The potential impact of climate change on soil properties and processes and corresponding influence on food security. Agriculture 2013, 3, 398-417. [CrossRef]

7. Iizumi, T.; Ramankutty, N. How do weather and climate influence cropping area and intensity? Glob. Food Sec. 2015, 4, 46-50. [CrossRef]

8. Taiz, L. Agriculture, plant physiology, and human population growth: Past, present, and future. Theor. Exp. Plant Physiol. 2013, 25, 167-181. [CrossRef] 
9. FAOSTAT. Food and Agriculture Organization of the United Nations. Available online: http://faostat.fao.org/site/567/default. aspx\#ancor (accessed on 25 October 2020).

10. Ray, D.K.; Mueller, N.D.; West, P.C.; Foley, J.A. Yield trends are insufficient to double global crop production by 2050. PLoS ONE 2013, 8, e66428. [CrossRef] [PubMed]

11. Cormier, F.; Foulkes, J.; Hirel, B.; Gouche, D.; Moënne-Loccoz, Y.; Le Gouis, J. Breeding for increased nitrogen-use efficiency: A review for wheat. Plant Breed. 2016, 135, 255-278. [CrossRef]

12. Smith, P.; Gregory, P.J.; van Vuuren, D.; Obersteiner, M.; Havlik, P.; Rounsevell, M.; Woods, J.; Stehfest, E.; Bellarby, J. Competition for land. Phil. Trans. R. Soc. B 2010, 365, 2941-2957. [CrossRef]

13. FAO. The State of the World's Land and Water Resources for Food and Agriculture (SOLAW)—Managing Systems at Risk; Food and Agriculture Organization of the United Nations and Earthscan: Rome, Italy, 2011.

14. Conway, G. The Doubly Green Revolution: Food for All in the Twenty-First Century; Penguin Books: London, UK, 1997.

15. Spiertz, J.H.J. Nitrogen, sustainable agriculture and food security. A review. Agron. Sustain. Dev. 2010, 30, 43-55. [CrossRef]

16. Pretty, J.; Bharucha, Z.P. Sustainable intensification in agricultural systems. Ann. Bot. 2014, 114, 1571-1596. [CrossRef]

17. The Royal Society. Reaping the Benefits: Science and the Sustainable Intensification of Global Agriculture; RS Policy document; The Royal Society: London, UK, 2009; p. 86.

18. Smith, P. Delivering food security without increasing pressure on land. Global Food Sec. 2013, 2, 18-23. [CrossRef]

19. Godfray, H.C.; Garnett, T. Food security and sustainable intensification. Phil. Trans. R. Soc. B 2014, 369, 20120273. [CrossRef] [PubMed]

20. Rockström, J.; Williams, J.; Daily, G.; Noble, A.; Matthews, N.; Gordon, L.; Wetterstrand, H.; DeClerck, F.; Shah, M.; Steduto, P.; et al. Sustainable intensification of agriculture for human prosperity and global sustainability. Ambio 2017, 46, 4-17.

21. Grafton, R.Q.; Williams, J.; Jiang, Q. Food and water gaps to 2050: Preliminary results from the global food and water systems (GFWS) platform. Food Sec. 2015, 7, 209-220. [CrossRef]

22. Mogollón, J.M.; Lasaletta, L.; Beusen, A.H.W.; van Grinsven, H.J.M.; Westhoek, H.; Bouwman, A.F. Assessing future reactive nitrogen inputs into global croplands based on the shared socioeconomic pathways. Environ. Res. Lett. 2018, 13, 044008.

23. Conijn, J.G.; Bindraban, P.S.; Schröder, J.J.; Jongschaap, R.E.E. Can our global food system meet food demand within planetary boundries? Agric. Ecosys. Environ. 2018, 251, 244-256. [CrossRef]

24. Bodirsky, B.L.; Popp, A.; Lotze-Campen, H.; Dietrich, J.P.; Rolinski, S.; Weindl, I.; Smitz, C.; Müller, C.; Bonsch, M.; Humpenöder, F.; et al. Reactive nitrogen requirements to feed the world in 2050 and potential to mitigate nitrogen pollution. Nat. Commun. 2014, 5, 3858. [CrossRef] [PubMed]

25. Pradhan, P.; Fischer, G.; van Velthuizen, H.; Reusser, D.E.; Kropp, J.P. Closing yield gaps: How sustainable can we be? PLoS ONE 2015, 10, e0129487. [CrossRef] [PubMed]

26. Grzebisz, W.; Gransee, A.; Szczepaniak, W.; Diatta, J. The effects of K fertilization on water-use efficiency in crop plants. J. Plant Nutr. Soil Sci. 2013, 176, 355-374. [CrossRef]

27. Wang, Z.; Hassan, M.U.; Nadeem, F.; Wu., L.; Zhang, F.; Li, X. Magnesium Fertilization improves crop yield in most production systems: A meta-analysis. Front. Plant Sci. 2019, 10, 1727. [CrossRef]

28. Rabbinge, R. The ecological background of food production. In Crop Production and Sustainable Agriculture; Rabbinge, R., Ed.; John Wiley and Sons: New York, NY, USA, 1993; pp. 2-29.

29. Evans, L.T.; Fischer, R.A. Yield potential: Its definition, measurement, and significance. Crop Sci. Soc. Am. 1999, 39, 1544-1551. [CrossRef]

30. Van Ittersum, M.K.; Cassman, K.G.; Grassini, P.; Wolf, J.; Tittonell, P.; Hochman, Z. Yield gap analysis with local to global relevance-a review. Field Crops Res. 2013, 143, 4-17. [CrossRef]

31. Van Wart, J.; Kersebaum, K.C.; Peng, S.; Milner, M.; Cassman, K.C. Estimating crop yield potential at regional to national scales. Field Crops Res. 2013, 143, 34-43. [CrossRef]

32. Liu, J.; Williams, J.R.; Zehnder, A.J.B.; Yang, H. GEPIC—modelling wheat yield and crop water productivity with high resolution on a global scale. Agric. Syst. 2007, 94, 478-493. [CrossRef]

33. Agnus, J.F.; van Herwaarden, A.F. Increasing water use and water use efficiency in dryland wheat. Agron. J. 2001, 93, 290-298.

34. Passioura, J. Increasing crop productivity when water is scares-from breeding to field management. Agric. Water Manage. 2006, 80, 176-196. [CrossRef]

35. Licker, R.; Johnston, M.; Foley, J.A.; Barford, C.; Kucharik, C.J.; Monfreda, C.; Ramankutty, N. Mind the gap: How do climate and agricultural management explain the "yield gap" of croplands around the world? Glob. Ecol. Biogeogr. 2010, 19, 769-782. [CrossRef]

36. Iwańska, M.; Paderewski, J.; Stępień, M.; Rodrigues, P.C. Adaptation of winter wheat cultivars to different environments: A case study in Poland. Agronomy 2020, 10, 632. [CrossRef]

37. Studnicki, M.; Lenartowicz, M.; Noras, K.; Wójcik-Gront, E.; Wyszyński, Z. Assessment of stability and adaptation patterns of white sugar yield from sugar beet cultivars in temperate climate environments. Agronomy 2019, 9, 405. [CrossRef]

38. Rubio, G.; Zhu, J.; Lynch, J. A critical test of the prevailing theories of plant response to nutrient availability. Am. J. Botany 2003, 90-91, 143-152. [CrossRef]

39. Grzebisz, W.; Łukowiak, R.; Sassenrath, G. Virtual nitrogen as a tool for assessment of nitrogen at the field scale. Field Crops Res. 2018, 218, 182-184. [CrossRef] 
40. Łukowiak, R.; Grzebisz, W.; Ceglarek, J.; Podolski, A.; Kaźmierowski, C.; Piekarczyk, J. Spatial variability of yield and nitrogen indicators-a crop rotation approach. Agronomy 2020, 10, 1959. [CrossRef]

41. Cassman, G.; Dobermann, A.; Walters, D. Agro-ecosystems, nitrogen-use efficiency, and nitrogen Management. Ambio 2002, 31, 132-140. [CrossRef]

42. Grzebisz, W.; Diatta, J. Constrains and solutions to maintain soil productivity, a case study from Central Europe. In Soil Fertility Improvement and Integrated Nutrient Management_A Global Perspective; Whalen, J., Ed.; InTech: London, UK, $2012 ;$ pp. 159-183. ISBN 978-953-307-945-5.

43. Wallace, A.; Wallace, G.A. Closing the Crop-Yield Gap through Better Soil and Better Management; Wallace Laboratories: Los Angeles, CA, USA, 2003; p. 162.

44. Vogel, E.; Donat, M.G.; Alexander, L.V.; Meinshausen, M.; Ray, D.K.; Karoly, D.; Meinshausen, N.; Frieler, K. The effects of climate extremes on global agricultural yields. Environ. Res. Lett. 2019, 14, 054010. [CrossRef]

45. Tóth, G.; Hermann, T.; Da Silva, M.R.; Montanarella, L. Monitoring soil for sustainable development and land degradation neutrality. Environ. Monit. Assess. 2018, 190, 57. [CrossRef] [PubMed]

46. Mueller, L.; Schindler, U.; Mirschel, W.; Shepherd, T.G.; Ball, B.C.; Helming, K.; Rogasik, J.; Eulenstein, F.; Wiggering, H. Assessing the productivity of soil. A review. Agron. Sustain. Dev. 2010, 30, 601-614. [CrossRef]

47. Patzel, N.; Sticher, H.; Karlen, D.L. Soil fertility-phenomenon and concept. J. Plant Nutr. Soil Sci. 2000, 163, 129-140. [CrossRef]

48. Haberle, J.; Svoboda, P. Calculation of available water supply in crop root zone and the water balance of crops. Contrib. Geophys. Geod. 2015, 45/4, 285-298. [CrossRef]

49. Fatichi, S.; Or, D.; Walko, R.; Vereecken, H.; Young, M.H.; Ghezzehei, T.A.; Hengl, T.; Kollet, S.; Agam, N.; Avissar, R. Soil structure is an important omission in Earth System Models. Nat. Commun. 2020, 11, 522. [CrossRef] [PubMed]

50. Kristensen, J.A.; Balstrøm, T.; Jones, R.J.A.; Jones, A.; Montanarella, L.; Panagos, P.; Breuning-madsen, H. Development of a harmonized soil profile analytical database for Europe: A resource for supporting regional soil management. Soil 2019, 5, $289-301$. [CrossRef]

51. Knebl, L.; Leithold, G.; Schulz, F.; Brock, C. The role of soil depth in the evaluation of management-induced effects on soil organic matter. Eur. J. Soil Sci. 2017, 68, 979-987. [CrossRef]

52. Baldock, J.A.; Skjemstad, J.O. Role of the soil matrix and minerals in protecting natural organic materials against biological attack. Organic Chem. 2000, 31, 697-710. [CrossRef]

53. Lovelland, P.; Webb, J. Is there a critical level of organic matter in the agricultural soils of temperate regions: A review. Soil Tillage Res. 2003, 70, 1-18. [CrossRef]

54. Piéri, C. Fertilité des Terres de Savanes. Bilan de trente années de recherches et de développement gricole au sud du Sahara; Ministère de la Coopération et du Développement, CIRAD: Paris, France, 1989; p. 444.

55. Spychalski, W.; Grzebisz, W.; Diatta, J.; Kostarev, D. Humus stock degradation and its impact on phosphorus forms in arable soils-a case of Ukrainian Forest-Steppe Zone. Chem. Speciation Bioavail. 2018, 30, 33-46. [CrossRef]

56. Bauer, A.; Black, A.L. Quantification of the effect of soil organic matter content on soil productivity. Soil Sci. Soc. Am. J. 1994, 58, 185-193. [CrossRef]

57. Batjes, N.H. carbon and nitrogen stocks in the soils of Central and Eastern Europe. Soil Use Manag. 2002, 18, 324-329. [CrossRef]

58. Libohova, Z.; Seybold, C.; Wysocki, D.; Wills, S.; Schoeneberger, P.; Williams, C.; Lindbo, D.; Stott, D.; Owens, P.R. Reevaluating the effects of soil organic matter and other properties on available water-holding capacity using the National Cooperative Survey Characterization Database. J. Soil Water Conserv. 2018, 73, 411-421. [CrossRef]

59. Ludwig, B.; Geisseler, D.; Michel, K.; Joergensen, R.G.; Schulz, E.; Merbach, I.; Raupp, J.; Rauner, R.; Hu, K.; Niu, L.; et al. Effects of fertilization and soil management on crop yields and carbon stabilization in soils. A review. Agron. Sustain. Dev. 2011, 31, 361-372. [CrossRef]

60. Wu, T.; Schoenau, J.J.; Li, F.; Qian, P.; Malhi, S.S.; Shi, Y.; Xu, F. Influence of cultivation and fertilization on total organic carbon and carbon fractions in soils from the Loess Plateau of China. Soil Tillage Res. 2004, 77, 59-68. [CrossRef]

61. Powlson, D.; Smith, P.; Coleman, K.; Smith, J.U.; Glendining, M.J.; Körschens, M.; Franko, U. A European network of long-term sites for studies on soil organic matter. Soil Tillage Res. 1998, 47, 263-274. [CrossRef]

62. Szajdak, L.; Życzyńska-Bałoniak, I.; Meysner, T.; Blecharczyk, A. Bound amino acids in humic acids from arable cropping systems. J. Plant Nutr. Soil Sci. 2004, 167, 562-567. [CrossRef]

63. Zhao, X.; Yuan, G.; Wang, H.; Lu, D.; Chen, X.; Zhou, J. Effects of full straw incorporation on soil fertility and crop yield in rice-wheat rotation for silty clay loamy cropland. Agronomy 2019, 9, 133. [CrossRef]

64. Noordwijk van, M.; Cadisch, G. Access and excess problems in soil nutrition. Plant Soil 2002, 247, 25-40. [CrossRef]

65. Ballabio, C.; Lugato, E.; Fernandez-Ugalde, O.; Orgiazzi, A.; Jones, A.; Borelli, P.; Montanarella, L.; Panagos, P. Mapping LUCAS topsoil chemical properties in European scale using Gaussian process regression. Geoderma 2019, 355, 113912. [CrossRef]

66. Bloom, A.J. Nitrogen dynamics in plant growth systems. Life Support Biosph. Sci. 1996, 3, 35-41. [PubMed]

67. Krouk, G.; Ruffel, S.; Gutiérrez, R.A.; Gojon, A.; Crawford, N.M.; Coruzzi, G.M.; Lacombe, B. A framework integrating plant growth with hormones and nutrients. Trends Plant Sci. 2011, 16, 178-182. [CrossRef]

68. Smucker, A.J.M.; Aiken, R.M. Dynamic root responses to water deficits. Soil Sci. 1992, 154, 281-289. [CrossRef]

69. Bodner, G.; Nakhforoosh, A.; Kaul, H.P. Management of crop water under drought: A review. Agron. Sustain. Dev. 2015, 35, 401-442. [CrossRef] 
70. Zhang, F.; Niu, J.; Zhang, W.; Chen, X.; Li, C.; Yuan, L.; Xie, J. Potassium nutrition of crops under varied regimes of nitrogen supply. Plant Soil 2010, 335, 21-34. [CrossRef]

71. Blanchet, G.; Libohiva, Z.; Joost, S.; Rossier, N.; Schneider, A.; Jeangross, B.; Sinaj, A. Spatial variability of potassium in agricultural soils of the canton of Fribourg, Switzerland. Geoderma 2017, $107-121$. [CrossRef]

72. Gao, X.-S.; Xiao, Y.; Deng, L.-J.; Wang, C.; Deng, O.; Zeng, M. Spatial variability of total nitrogen, phosphorus and potassium in Renshou County of Sichuan Basin, China. J. Integr. Agric. 2019, 18, 279-289. [CrossRef]

73. Boring, T.J.; Thelen, K.D.; Board, J.E.; Board, J.E.; De Bruis, J.L.; Lee, C.D.; Naeve, S.L.; Ross, W.J.; Kent, W.A.; Ries, L.L. Phosphorus and potassium fertilizer application strategies in corn-soybean rotations. Agronomy 2018, 8, 195. [CrossRef]

74. Penn, C.J.; Camberato, J.J. A critical review on soil chemical processes that control how soil $\mathrm{pH}$ affects phosphorus availability to plants. Agriculture 2019, 9, 120. [CrossRef]

75. Pasket, A.; Zhang, H.; Raun, W.; Deng, S. Recovery of phosphorus in soil amended with manure for 119 years. Agronomy 2020, 10, 1947. [CrossRef]

76. Kautz, T.; Amelung, W.; Ewert, F.; Gaiser, T.; Horn, R.; Jahn, R.; Javaux, M.; Kemna, A.; Kuzyakova, Y.; Munch, J.-C.; et al. Nutrient acquisition from arable subsoils in temperate climates: A review. Soil Biol. Biochem. 2013, 57, 1003-1022. [CrossRef]

77. White, C.; Sylvester-Bradley, R.; Berry, P.M. Root length densities of UK wheat and oilseed rape crops with implications for water capture and yield. J. Exp. Bot. 2015, 66, 2293-2303. [CrossRef]

78. Barraclough, P.B. Root growth, macro-nutrient uptake dynamics and soil fertility requirements of a high-yielding winter oilseed rape crop. Plant Soil 1989, 119, 59-70. [CrossRef]

79. Łukowiak, R.; Grzebisz, W.; Sassenrath, G. New insights into phosphorus management in agriculture-A crop rotation approach. Sci. Total Environ. 2016, 542, 1062-1077. [CrossRef] [PubMed]

80. Grzebisz, W.; Łukowiak, R.; Kotnis, K. Evaluation of nitrogen fertilization systems based on the in-season variability of the nitrogenous growth factors and soil fertility factors-a case of winter oilseed rape (Brassica napus L.). Agronomy 2020, $10,1701$. [CrossRef]

81. Bauke, S.L.; von Sperber, C.; Tamburini, F.; Gocke, M.I.; Honermeier, B.; Schweitzer, K.; Baumecker, M.; Don, A.; SandhageHofmann, A.; Amelung, W. Subsoil phosphorus is affected by fertilization regime in long-term agricultural experimental trials. Europ. J. Soil Sci. 2018, 69, 103-112. [CrossRef]

82. Barłóg, P.; Łukowiak, R.; Grzebisz, W. Predicting the content of soil mineral nitrogen based on the content of calcium chlorideextractable nutrients. J. Plant Nutr. Soil Sci. 2017, 180, 624-635. [CrossRef]

83. Łukowiak, R.; Barłóg, P.; Grzebisz, W. Soil mineral nitrogen and the rating of $\mathrm{CaCl}_{2}$ extractable nutrients. Plant Soil Environ. 2017, 63, 177-183.

84. Fan, J.; Mc Conkey, B.; Wang, H.; Janzen, H. Root distribution by depth for temperate agricultural crops. Field Crops Res. 2016, 189, 68-74. [CrossRef]

85. Forde, B.; Lorenzo, H. The nutritional control of root development. Plant Soil 2001, 232, 51-68. [CrossRef]

86. Marschner, P. (Ed.) Marchnerr's Mineral Nutrition of Higher Plants, 3rd ed.; Academic Press: London, UK, 2012 ; p. 672.

87. Grzebisz, W.; Szczepaniak, W.; Barłóg, P.; Przygocka-Cyna, K.; Potarzycki, J. Phosphorus sources for winter oilseed rape (Brassica napus L.) during reproductive growth-magnesium sulfate management impact on P use efficiency. Arch. Agron. Soil Sci. 2018, 64, 1646-1662. [CrossRef]

88. Grzebisz, W.; Kryszak, J. Effect of soil fertility on root morphology of winter rye. In Root Ecology and Its Practical Application; Kutschera, L., Hübl, E., Lichtenegger, E., Persson, H., Sobotik, M., Eds.; Verein fot Wurzelforschung: Klagenfurt, Austria, 1992; pp. 389-392.

89. Barber, S.A. Soil Nutrient Bioavailability: A Mechanistic Approach, 2nd ed.; Wiley and Sons: New York, NY, USA, 1995.

90. Gaju, O.; Allard, V.; Martre, P.; Le Gouis, J.; Moreau, D.; Bogard, M.; Hubbart, S.; Foulkes, M.J. Nitrogen partitioning and remobilization to leaf senescence, grain yield and grain nitrogen concentration in wheat cultivars. Field Crops Res. 2014, 155, 213-223. [CrossRef]

91. Hawkesford, M.J. Reducing the reliance on nitrogen fertilization for wheat production. J. Cereal Sci. 2014, 59, 276-283. [CrossRef] [PubMed]

92. Maeoka, R.E.; Sadras, V.O.; Ciampitti, I.A.; Diaz, D.R.; Fritz, A.K.; Lollato, R.P. Changes in the phenotype of winter wheat varieties released between 1920 and 2016 in response to in-furrow fertilizer: Biomass allocation, yield, and grain protein concentration. Front. Plant Sci. 2019, 10, 1786. [CrossRef]

93. Hawkesford, M.J.; Riche, A.B. Impacts of G x E x M on nitrogen use efficiency in wheat and future prospects. Front. Plant Sci. 2020, 11, 1157. [CrossRef]

94. Malhi, S.S.; Johnston, A.M.; Schoenaou, J.J.; Wang, Z.H.; Vera, C.L. Seasonal biomass accumulation and nutrient uptake of wheat, barley, and oak on a Black Chernozem soil in Saskatchewan. Can. J. Plant Sci. 2006, 86, 1005-1014. [CrossRef]

95. Zhou, G.; Wang, Q. A new nonlinear method for calculating growing degree days. Sci. Rep. 2018, 8, 10149. [CrossRef] [PubMed]

96. Yin, X.; Goudriaan, J.; Lantinga, E.A.; Vos, J.; Spiertz, H. A flexible sigmoid function of determinate growth. Ann. Bot. 2003, 91,361-371. [CrossRef] [PubMed]

97. Zerche, S.; Hecht, R. Nitrogen uptake of winter wheat during shoot elongation phase in relation to canopy high and shoot density. Agribiol. Res. 1999, 52, 231-250. 
98. Kahabka, J.E.; Van Es, H.M.; McClenahan, E.J.; Cox, W.J. Spatial analysis of maize response to nitrogen fertilizer in Central New York. Precision Agric. 2004, 5, 463-476. [CrossRef]

99. Luce, M.S.; Whalen, J.K.; Ziadi, N.; Zebarth, B.J. Nitrogen dynamics and indices to predict soil nitrogen supply in humid temperate soils. Adv. Agron. 2011, 112, 55-102.

100. Richards, R.A. Selectable traits to increase crop photosynthesis and yield of grain crops. J. Exp. Bot. 2000, 51, 337-458. [CrossRef]

101. Szczepaniak, W. A mineral profile of oilseed rape in critical stages of growth-nitrogen. J. Elem. 2014, 19, 759-778. [CrossRef]

102. Grzebisz, W.; Szczepaniak, W.; Grześ, S. Sources of nutrients for high-yielding winter oilseed rape (Brassica napus L.) during post-flowering growth. Agronomy 2020, 10, 626. [CrossRef]

103. Spiertz, J.; Vos, J. Grain Growth of Wheat and Its Limitation by Carbohydrate and Nitrogen Supply. In Wheat Growth and Modelling; Day, W., Atkin, R., Eds.; Plenum Press: New York, NY, USA, 1985.

104. Barraclough, P.B.; Lopez-Bellido, R.; Hawkesford, M. Genotypic variation in the uptake, partitioning and remobilization of nitrogen during grain-filling in wheat. Field Crops Res. 2014, 156, 242-248. [CrossRef]

105. Taulemesse, F.; Le Gouis, J.; Gouache, D.; Gibon, Y.; Allard, V. Bread wheat (Triticum aestivum L.) grain protein concentration is related to early post-flowering nitrate uptake under putative control of plant satiety level. PLoS ONE 2016, 11, e0149668. [CrossRef] [PubMed]

106. Bogard, M.; Allard, V.; Brancourt-Hulmel, M.; Heumez, E.; Machet, J.-M.; Jeufforoy, M.-H.; Gate, P.; Le Gouis, J. Deviation from the grain protein concentration-grain yield negative relationships is highly correlated to post-anthesis $\mathrm{N}$ uptake by winter wheat. J. Exp. Bot. 2010, 15, 4303-4312. [CrossRef]

107. Subedi, K.; Ma, B. Nitrogen uptake and partitioning in stay-green and leafy maize hybrids. Crops Sci. 2005, 45, 740-747. [CrossRef]

108. Grzebisz, W.; Wrońska, M.; Diatta, J.B.; Szczepaniak, W. Effect of zinc application at early stages of maize growth on the patterns of nutrients and dry matter accumulation by canopy. Part, I. Nitrogen uptake and dry matter accumulation patterns. J. Elem. 2008, 13, 17-28.

109. Kovacs, P.; Vyn, T.J. Relationships between earl-leaf nutrient concentration at silking and corn biomass and grain yield at maturity. Agron. J. 2017, 109, 2898-2906. [CrossRef]

110. Szczepaniak, W.; Barłóg, P.; Łukowiak, R.; Przygocka-Cyna, K. Effect of balanced nitrogen fertilization in four-year rotation on plant productivity. J. Central Europ. Agroc. 2013, 14, 64-77. [CrossRef]

111. Szczepaniak, W.; Grzebisz, W.; Potarzycki, J.; Łukowiak, R.; Przygocka-Cyna, K. Nutritional status of winter oilseed rape in cardinal stages of growth as yield indicator. Plant Soil Environ. 2015, 61, 291-296. [CrossRef]

112. Weih, M.; Hamnér, K.; Pourazari, F. Analyzing plant nutrient uptake and utilization efficiencies: Comparison between crops and approaches. Plant Soil 2018, 430, 7-21. [CrossRef]

113. White, P.J.; Brown, P.H. Plant nutrition for sustainable development and global health. Ann. Bot. 2010, 105, 1073-1080. [CrossRef]

114. Tan, Z.X.; Lal, R.; Wiebe, K.D. Global soil nutrient depletion and yield reduction. J. Sustain. Develop. 2015, 26, 123-146. [CrossRef]

115. Mi, G.-H.; Chen, F.-J.; Wu, Q.-P.; Lai, N.-W.; Yuan, L.-X. Ideotype root architecture for effcient nitrogen acqusition by maize in intensive cropping systems. Sci. China Life Sci. 2010, 553, 1369-1373. [CrossRef] [PubMed]

116. Ruiz Herrera, L.F.; Shane, M.W.; López-Bucio, J. Nutritional regulation of root development. WIREs Dev. Biol. 2015, 4, 431-443. [CrossRef]

117. Lynch, J.P. Root phenothypes for improved nutrient capture: An underexploited opportunity for global agriculture. New Phytol. 2019, 223, 548-564. [CrossRef]

118. Duque, L.O.; Villordon, A. Root branching and nutrient efficiency: Status and way forward in root and tuber crops. Front. Plant Sci. 2019, 10, 237. [CrossRef]

119. Fageria, N.K.; Moreira, A. The role of mineral nutrition on root growth of crop plants. Adv. Agron. 2011, $110,3-83$.

120. Metwally, M.S.; Shaddad, S.M.; Liu, M.; Yao, R.-J.; Abdo, A.; Li, P.; Jiao, J.; Chen, X. Soil properties spatial variability and delineation of site-specific management zones based on soil fertility using fuzzy clustering in a hilly field in Jianyang, Sichuam, China. Sustainability 2019, 11, 7084. [CrossRef]

121. Erisman, J.W.; Leach, A.; Bleeker, A.; Atwell, B.; Cattaneo, L.; Galloway, J. An integrated approach to a nitrogen use efficiency (NUE) indicator for the food production-consumption chain. Sustainability 2018, 10, 925. [CrossRef]

122. Moll, R.H.; Kamprath, E.J.; Jackson, W.A. Analysis and interpretation of factors which contribute to efficiency of nitrogen utilization. Agron. J. 1982, 74, 562-564. [CrossRef]

123. Swaney, D.P.; Howarth, R.W.; Hong, B. Nitrogen use efficiency and crop production: Patterns of regional variation in the United States, 1987-2012. Sci. Tot. Environ. 2018, 635, 498-511. [CrossRef]

124. Pan, W.L.; Kidwell, K.K.; McCracken, V.A.; Bolton, R.P.; Allen, M. Economically optimal wheat yield, protein and nitrogen use component responses to varying N supply and genotype. Front. Plant Sci. 2020, 10, 1790. [CrossRef] [PubMed]

125. Yin, X.; Struik, P.C. Constrains tot he potential Efficiency of converting solar radiation into phytoenergy in annual crops: From leaf biochemistry to canopy physiology an crop ecology. J. Exp. Bot. 2015, 66, 6535-6549. [CrossRef] [PubMed]

126. Papadopoulos, A.; Kalivas, D.; Hatzichrostos, T. GIS modeling for site-specific nitrogen fertilization towards soil sustainability. Sustainability 2015, 7, 6684-6705. [CrossRef]

127. Gulser, C.; Ekberli, I.; Candemier, F.; Demir, Z. Spatial variability of soil physical properties in a cultivated field. Eurasian J. Soil Sci. 2016, 5, 192-200. [CrossRef] 
128. Córdova, C.; Barrera, J.A.; Magna, C. Spatial variation in nitrogen mineralization as a guide for variable application of nitrogen fertilizer to cereal crops. Nutr. Cycl. Agroecosyst. 2018, 110, 83-88. [CrossRef]

129. Denton, O.A.; Aduramigba-Modupe, V.O.; Ojo, A.O.; Adeoyolanu, O.D.; Are, K.S.; Adelana, A.; Oyedele, A.O.; Adetayo, A.O.; Olubukola, O.A. Assessment of spatial variability and mapping of soil properties for sustainable agricultural production using geographic information system techniques (GIS). Cogent Food Agric. 2017, 3, 1279366. [CrossRef]

130. Vasu, D.; Singh, S.K.; Sahu, N.; Tiwary, P.; Chandran, P.; Duraisami, V.P.; Ramamurthy, V.; Lalitha, M.; Kaliselvi, B. Assessment of spatial variability of soil properties using geostatical techniques for farm level nutrient management. Soil Tillage Res. 2017, 169, 25-34. [CrossRef]

131. Lemaire, G.; Jeuffroy, M.-H.; fstal, F. Diagnosis toll for plant an crop N status in vegetative stage: Theory and practices for crop N management. Eur. J. Agron. 2008, 28, 181-190. [CrossRef]

132. Song, L.; Wang, S.; Ye, W. Establishment and application of critical nitrogen dilution curves for rice based on leaf dry matter. Agronomy 2020, 10, 367. [CrossRef]

133. Chen, Z.; Miao, Y.; Lu, J.; Zhou, L.; Li, Y.; Zhang, H.; Lou, W.; Zhang, Z.; Kusnierek, K.; Liu, C. In-season diagnosis of winter wheat nitrogen status in smallholder farmer fields across a village using unmanned aerial vehicle-based remote sensing. Agronomy 2019, 9, 619. [CrossRef]

134. Stamatiadis, S.; Schepers, J.S.; Evangelou, E.; Tsadilas, C.; Glampedakis, M.; Dercas, N.; Spyropoulos, N.; Dalezios, N.R.; Eskridge, K. Variable-rate nitrogen fertilization of winter wheat under high spatial resolution. Precision Agric. 2018, 19, 570-587. [CrossRef]

135. Sharma, L.K.; Bali, S.K. A review of methods to improve nitrogen use efficiency in agriculture. Sustainability $2018,10,51$. [CrossRef]

136. Li, H.; Zhang, Y.; lei, Y.; Antoniuk, V.; Hu, C. Evaluating different non-destructive estimation methods for winter wheat (Triticum aestivum L.) nitrogen status based on canopy spectrum. Remote Sens. 2020, 12, 95. [CrossRef]

137. Nigon, T.J.; Yang, C.; Paiao, G.D.; Mulla, D.J.; Knight, J.F.; Fernández, F.G. Prediction of early season nitrogen uptake by maize using high-resolution aerial hyperspectral imagery. Remote Sens. 2020, 12, 1234. [CrossRef]

138. Rodrigues, F.A.; Blasch, G.; Defourny, P.; Ortiz-Monasterio, J.I.; Schulthess, U.; Zarco-Tejada, P.J.; Taylor, J.A.; Gérard, B. Multitemporal and spectra analysis of high-resolution hyperspectral airborne imagery for precision agriculture: Assessment of wheat grain yield and grain protein content. Remote Sens. 2018, 10, 930. [CrossRef] [PubMed]

139. Cabrera-Bosquet, L.; Molero, G.; Stellacci, A.M.; Bort, J.; Nogués, S.; Araus, J.L. NDVI as a potential tool for predicting biomass, plant nitrogen content and growth in wheat genotypes subjected to different water and nitrogen conditions. Cereal Res. Comm. 2011, 39, 147-159. [CrossRef]

140. Vizzari, M.; Santaga, F.; Benincasa, P. Sentinel 2-based nitrogen VRT fertilization in wheat: Comparison between traditional and simple precision practices. Agronomy 2019, 9, 278. [CrossRef]

141. Argento, F.; Anken, T.; Abt, F.; Vogelsanger, E.; Walter, A.; Liebisch, F. Site-specific nitrogen management in winter wheat supported by low-altitude remote sensing and soil data. Precision Agric. 2020. [CrossRef]

142. Feng, W.; Wu, Y.; He, L.; ren, X.; Wang, Y.; Hou, G.; Wang, Y.; Liu, W.; Guo, T. An optimized non-linear vegetation index for estimating leaf area index in winter wheat. Precision Agric. 2019, 29, 1157-1176. [CrossRef]

143. Naser, M.A.; Khosla, R.; Longchamps, L.; Dahal, S. Using NDVI to differentiate wheat genotypes productivity under dryland and irrigated conditions. Remote Sens. 2020, 12, 824. [CrossRef]

144. Prey, L.; Schmidhalter, U. Sensitivity of vegetation indices for estimating vegetative N status in winter wheat. Sensors 2019, 19, 3712. [CrossRef] [PubMed]

145. Gerstmann, H.; Möller, M.; Gläßer, C. Optimization of spectra indices and long-term separability analysis for classification of cereal crops using multi-spectral RapidEye. Int. J. Appl. Earth Obs. 2016, 52, 115-125. [CrossRef] 